Research Article

\title{
Increase of Extreme Drought over Ethiopia under Climate Warming
}

\author{
Asaminew Teshome $\mathbb{D}^{1,2}$ and Jie Zhang $\mathbb{D}^{1}$ \\ ${ }^{1}$ Key Laboratory of Meteorological Disaster, Ministry of Education (KLME), \\ Joint International Research Laboratory of Climate and Environment Change (ILCEC), \\ Collaborative Innovation Center on Forecast and Evaluation of Meteorological Disasters (CIC-FEMD), \\ Nanjing University of Information Science \& Technology (NUIST), Nanjing 210044, China \\ ${ }^{2}$ National Meteorological Agency of Ethiopia, P.O. Box 1090, Addis Ababa, Ethiopia \\ Correspondence should be addressed to Jie Zhang; zhangj@nuist.edu.cn
}

Received 1 April 2019; Revised 22 June 2019; Accepted 8 July 2019; Published 25 August 2019

Academic Editor: Helena A. Flocas

Copyright ( $) 2019$ Asaminew Teshome and Jie Zhang. This is an open access article distributed under the Creative Commons Attribution License, which permits unrestricted use, distribution, and reproduction in any medium, provided the original work is properly cited.

\begin{abstract}
Recurrent extreme drought and flood in Ethiopia lead to more economic loss. This study examines change and trends of 21 climate extremes of temperature and precipitation over Ethiopia by using indices from the World Meteorological Organization (WMO) Expert Team on Climate Change Detection and Indices (ETCCDI). The analysis was based on the records of observed meteorological data and the future projected from the CMIP5 model under RCP 4.5 and RCP 8.5 scenarios. The results of the seasonal standardized rainfall anomaly and EOF analysis show a decreasing rainfall in JJAS season and significant variability in the FMAM season. The first mode of EOF in FMAM shows that $49.6 \%$ was mostly negative with a high amount of variability. The observed precipitation extreme of annual total precipitation (PRCPTOT), consecutive wet days (CWD), and the number of heavy precipitation days (R10) show a decreasing trend, and consecutive dry days (CDD) shows an increasing trend. Additionally, temperature extremes like tropical nights (TR20) and daily maximum and minimum temperatures show a significantly increasing trend. The projected precipitation extremes of CWD, PRCPTOT, very wet day annual total (R95p), and the number of heavy precipitation days (R10) show a decreasing trend. CDD shows longer periods of dryness and a substantial increase which is conducive to the increase of drought. The projected temperature extremes of the warm spell duration indicator (WSDI), daily maximum temperature (TXx) and daily minimum temperature (TNx), summer days (SU25), and tropical nights (TR20) show an increasing trend, while the diurnal temperature range shows a decreasing trend. The projected changes in temperature and precipitation extremes are likely to have significant negative impacts on various socioeconomic activities over Ethiopia. These results highlight the need for planning and developing effective adaptation strategies for disaster prevention.
\end{abstract}

\section{Introduction}

Warming of the climate system is unequivocal, and climate affects every aspect of nature and human life [1]. Recent reports by the Intergovernmental Panel on Climate Change (IPCC) indicated that the intensity and frequency of extremes are likely to increase over many areas including East Africa. The frequency and intensity of extremes like droughts, floods, and heat waves are expected to change as earth's climate changes, and these changes could occur even with relatively small mean climate changes [1-4].
Ethiopia is one of the largest humanitarian aid beneficiaries in the world and experiences significant climateinduced drought and water-related stresses on crop and livestock productivity [5]. Every year, approximately three million Ethiopians are affected by crop production shortfalls adding to the 7.6 million supported every year by the Productive Safety Net Program, a social safety net supporting some of Ethiopia's poorest and most food-insecure families [6] because of extreme drought. Very recently, the 2015 El Niño-induced drought has caused food insecurity among 10.2 million people, one of the highest on 
the record [7]. It is thus very important to analyze extreme events. One particular example in Ethiopia is droughts and floods that continuously occurred over northeastern, eastern, central, and northern parts of the country and recently became an annual problem for loss of lives and properties. Prolonged exposure to high-temperature extremes can cause heat-related illness, including heat cramps, heat exhaustion, heat stroke, and death. Elevated temperatures also have major consequences on livestock and terrestrial biota generally [8-10].

Understanding the occurrence of extreme weather events especially rainfall is important for decision-making as it is a key factor in prediction and risk assessment $[11,12]$. Extreme weather events are poised to have a higher impact as compared to mean climate [13]. Different studies have focused on ongoing and projected climate extremes; however, most of these studies have mainly focused on a global scale rather than regional and local scales. Past studies showed the observed reduction in a rainfall trend over East Africa especially in the March-May seasonal rainfall, and the reduction is consistent in various datasets ranging from gridded, observed, proxy, to model datasets [14-19]. There is a continuous reduction in the number of heavy rainy days observed over the Greater Horn of Africa including Ethiopia [20]. However, the spatial and temporal patterns, intensity, and impact of extreme climate on socioeconomic activities are different from region to region. So, to minimize the impact of extremes identifying extreme threats, responding to climate extremes through adaptation and mitigation to reduce the likelihood or severity of the extreme threat and recover from the extreme events quickly and efficiently is very important.

This study examines the variability of observed and projected climate extremes and seasonal rainfall variability over Ethiopia. Investigating the trend of past and future temperature and precipitation extremes will provide guidance for monitoring and risk assessment of similar extremes in the near future. Understanding the features of climate extremes at the regional to local scale is a key for designing response measures that enhance preparedness and early warning systems, and additionally in the long term, it helps in the formulation of effective adaptation planning measures to reduce the related risks.

\section{Data and Methodology}

2.1. Area of the Study. Ethiopia is located in the Horn of Africa within $3-15^{\circ} \mathrm{N}$ and $33-48^{\circ} \mathrm{E}$, bordered with Eritrea to the north, Djibouti to the east, Sudan to the west, Kenya to the south, and Somalia to the south and east. It covers an area of about 1.14 million square kilometers $(944,000$ square miles), and the country's topography consists of high and rugged plateaus and the peripheral lowlands. Elevations in the country range from 160 meters below the sea level (northern exit of the Rift Valley) to over 4600 meters above the sea level (northern mountainous regions) (Figure 1(a)). The highest mountains are concentrated on the northern and southern plateaus of the country [21]. Ethiopia has three climatological rainy seasons, namely, February-May
(FMAM, Belg), June-September (JJAS, Kiremt), and October-January (ONDJ, Bega) [22-28]. JJAS is the main rainy season, and the magnitude of rainfall is higher than other seasons for many parts of the country. FMAM is the smallest rainy period for most parts of Ethiopia. Rainfall during the FMAM season is highly variable in time and space, and also the highest maximum temperature occurs during FMAM. In contrast, the ONDJ season is the drier period for most parts of the country except southern and southeastern parts. Maximum mean annual rainfall amounts of 1750 to $2250 \mathrm{~mm}$ are observed over the southwestnorthwest parts of Ethiopia (Figure 1(c)).

2.2. Meteorological Data Description. Meteorological data records of daily precipitation, maximum and minimum temperature data of one hundred stations were obtained from the Ethiopian Meteorological Agency for the period from 1980 to 2010 . For seasonal rainfall analysis, we used one hundred stations, and based on rainfall distribution, three stations were selected to examine the annual observed and projected rainfall and temperature extremes (Figure 1(b)). Monthly reanalyzed rainfall data sourced from the Climate Research Unit (CRU) were used to assess the seasonal rainfall performance of Ethiopia. The CRU TS4.01 is discussed at length by the University of East Anglia Climatic Research Unit [29] and accessed from https://data.ceda.ac. $\mathrm{uk} / / \mathrm{badc} / \mathrm{cru} / \mathrm{data} / \mathrm{cru}$ ts/cru_ts_4.01/data/ gridded at $0.5^{\circ}$ latitude by $0.5^{\circ}$ longitude resolution.

2.2.1. Data Quality Control. For this study, the quality control was carried out by using the R-based statistical package of RClimDex v1.0 and RHtest tools. The test is recommended by the World Meteorological Organization (WMO) to check the homogeneity of meteorological datasets and widely used by different researchers in climate extreme calculation studies [30]. This tool is capable of identifying duplicate dates, out-of-range values based on a defined threshold, outliers, coherence between maximum and minimum temperatures $\left(T_{\max }>T_{\min }\right)$, and consecutive days with equal values. The Expert Team on Climate Change Detection and Indices (ETCCDI) and World Meteorological Organization recommended a total of 27 core extremes [31-33]. For this study, we used twenty one extremes of temperature and precipitation (Table 1 ).

\subsection{Methodology}

2.3.1. Empirical Orthogonal Function (EOF). EOF analysis is used to investigate the performance of FMAM and JJAS seasonal rainfall over Ethiopia by using the monthly gridded CRU TS4.01 dataset. EOF is a statistical tool that compresses geophysical data fields in space and time which represent orthogonal spatial patterns (eigenvectors) and a corresponding time series of principal component analysis (PCA) and has been used in numerous climate diagnostic studies [34]. The eigenvector in EOF analysis shows the spatial variability as well as the variance. The EOF method isolates 


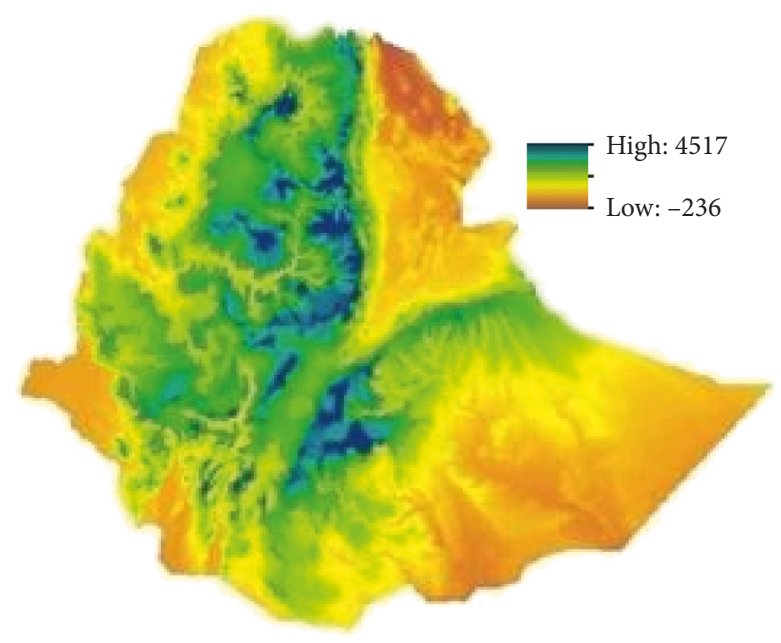

(a)

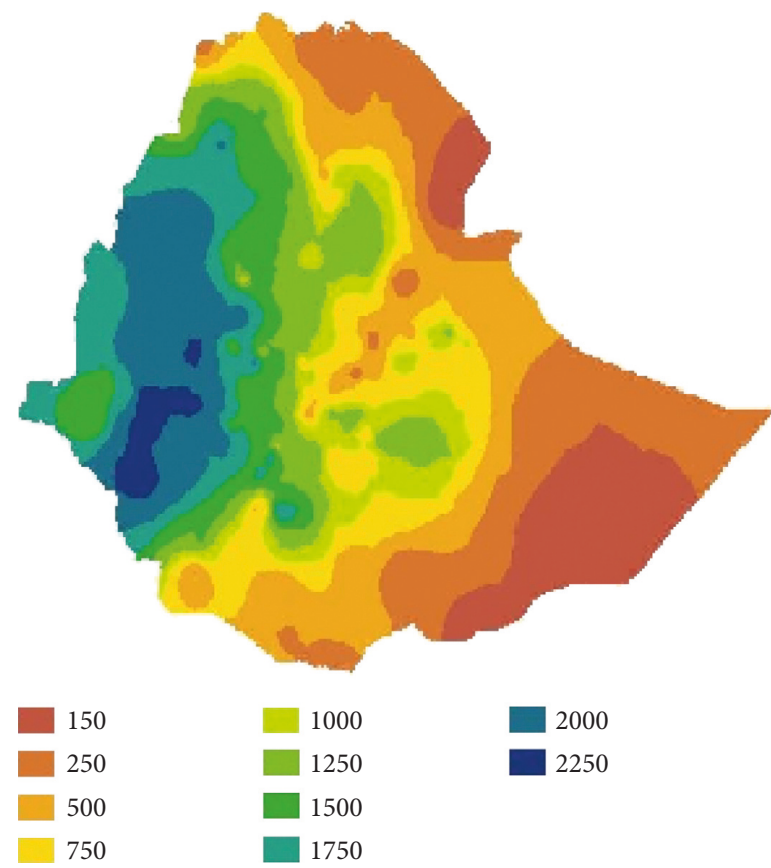

(c)

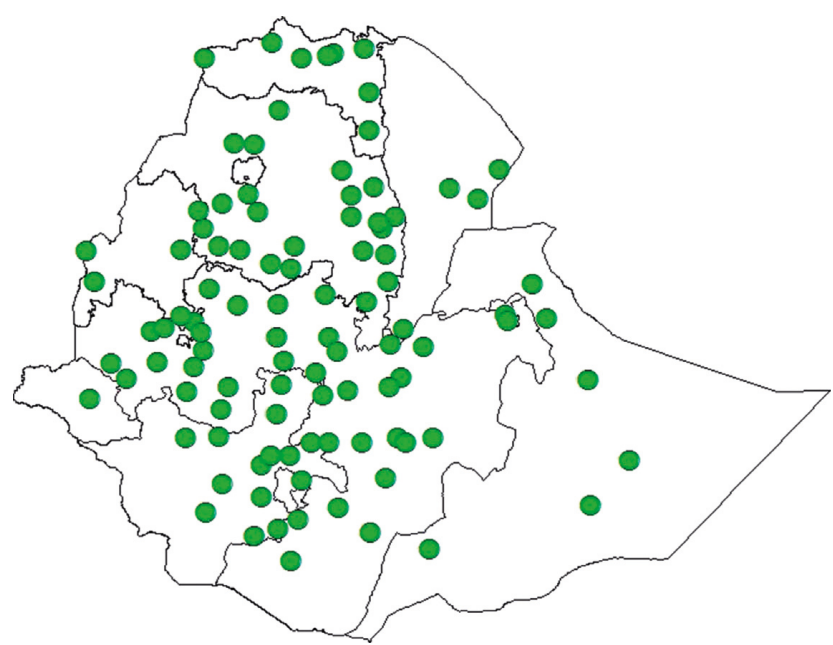

(b)

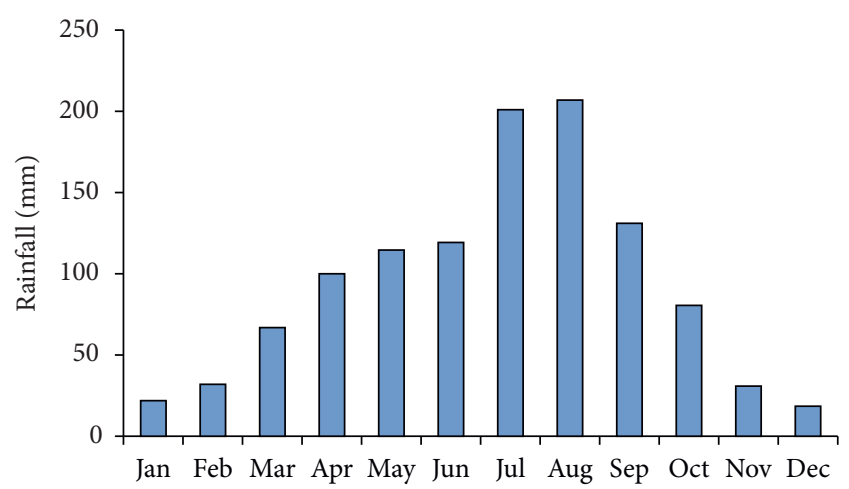

(d)

Figure 1: (a) Topographical map of Ethiopia (m). (b) Selected station distribution for this study. (c) Mean annual rainfall climatology (mm). (d) Monthly rainfall cycle $(\mathrm{mm})$.

the dominant mode of variability and decomposes into spatial and temporal patterns. The modes that account for the largest percent of the original variability are retained after satisfying the traditional statistical significance tests $[35,36]$. Different empirical techniques have been used to analyze the variability of rainfall. The EOF technique is one of the tools that have been proven to be successful at the regional scale. Ogallo [37] performed an EOF analysis to identify homogeneous regions of climate variability for eastern Africa, and the period of analysis was from 1922 to 1990. The primary concern was spatial variability of the climate. The EOF analysis allows us to explain the variance-covariance of the data through the modes of variability.
2.3.2. Seasonal Standardized Rainfall Anomaly (SRA). For each of the station seasonal mean precipitation, temperature and long-term mean seasonal rainfall and temperature series were analyzed for fluctuation using the standardized rainfall anomaly (SRA) which is commonly used for regional climate change studies [38, 39]. The results of SRA are presented graphically and in the tabular form, and the following equation is employed to calculate the SRA:

$$
\mathrm{SRA}=\frac{\left(S_{\mathrm{t}}-S_{m}\right)}{\sigma}
$$

where SRA is the standardized seasonal rainfall anomaly in season $t, S_{t}$ is the seasonal rainfall in season $t, S_{m}$ is the longterm mean seasonal rainfall over the period of observation, 
TABLE 1: List of the ETCCDI extremes investigated in this study.

\begin{tabular}{|c|c|c|c|}
\hline Elements & Index name & Definition & Units \\
\hline \multirow{10}{*}{ Temperature } & TMAXmean & Annual maximum temperature mean & ${ }^{\circ} \mathrm{C}$ \\
\hline & TMINmean & Annual minimum temperature mean & ${ }^{\circ} \mathrm{C}$ \\
\hline & SU25 & Annual count when TX (daily maximum) $>25^{\circ} \mathrm{C}$ & days \\
\hline & TR20 & Annual count when TN (daily minimum) $>20^{\circ} \mathrm{C}$ & days \\
\hline & TXx & Monthly maximum value of daily maximum temp. & ${ }^{\circ} \mathrm{C}$ \\
\hline & $\mathrm{TNx}$ & Monthly maximum value of daily minimum temp. & ${ }^{\circ} \mathrm{C}$ \\
\hline & TXn & Monthly minimum value of daily maximum temp. & ${ }^{\circ} \mathrm{C}$ \\
\hline & TNn & $\begin{array}{l}\text { Monthly value of daily minimum temp. when } \\
\text { TX }>\text { 90th percentile }\end{array}$ & ${ }^{\circ} \mathrm{C}$ \\
\hline & DTR & Monthly mean difference between TX and TN & ${ }^{\circ} \mathrm{C}$ \\
\hline & WSDI & $\begin{array}{c}\text { Annual count of days with at least } 6 \text { consecutive days } \\
\text { when TN }>90 \text { th percentile }\end{array}$ & days \\
\hline \multirow{11}{*}{ Precipitation } & RX1day & Monthly maximum 1-day precipitation & $\mathrm{mm}$ \\
\hline & RX5day & Monthly maximum consecutive 5-day precipitation & $\mathrm{mm}$ \\
\hline & SDII & $\begin{array}{l}\text { Annual total precipitation divided by the number of } \\
\text { wet days (defined as } P R C P \geq 1.0 \mathrm{~mm} \text { ) in the year }\end{array}$ & $\mathrm{mm} / \mathrm{day}$ \\
\hline & R10 & Annual count of days when $P R C P \geq 10 \mathrm{~mm}$ & days \\
\hline & $\mathrm{R} 20$ & Annual count of days when PRCP $\geq 20 \mathrm{~mm}$ & days \\
\hline & $\mathrm{R} 25$ & Annual count of days when $\mathrm{PRCP} \geq 25 \mathrm{~mm}$ & days \\
\hline & CDD & $\begin{array}{l}\text { Maximum number of consecutive days with } \\
\qquad \mathrm{RR}<1 \mathrm{~mm}\end{array}$ & days \\
\hline & CWD & $\begin{array}{l}\text { Maximum number of consecutive days with } \\
\qquad R R \geq 1 \mathrm{~mm}\end{array}$ & days \\
\hline & R95p & Annual total PRCP when PR $>$ 95th percentile & $\mathrm{mm}$ \\
\hline & R99p & Annual total PRCP when PR $>$ 99th percentile & $\mathrm{mm}$ \\
\hline & PRCPTOT & Annual total PRCP in wet days (RR $\geq 1 \mathrm{~mm})$ & $\mathrm{mm}$ \\
\hline
\end{tabular}

Note: full definitions are available at http://etccdi.pacificclimate.org/list_27_indices.shtml.

and $\sigma$ is the standardized deviation of seasonal rainfall over the period of observation.

\subsubsection{Projected Rainfall and Temperature Extreme Analysis.} To examine the future climate extremes, the rainfall and temperature datasets were used from Coupled Model Intercomparison Project Phase 5 (CMIP5), and the models are discussed in [40-42]. The three ensemble models employed for our study are CanESM2 with a resolution of $\sim 2.81 \times 2.79$ degrees from the Canadian Centre for Climate Modelling and Analysis (Canada), CSIRO-MK3.6.0 with a resolution of $\sim 1.875 \times 1.865$ degrees from the Commonwealth Scientific and Industrial Research Organisation (Australia), and GFDLESM2 with a resolution of $\sim 2.02 \times 2$ degrees from the National Oceanic and Atmospheric Administration (NOAA) and downloaded from PCMDI (http://pcmdi3.llnl. gov/esgcet). Additionally, RCP4.5 and RCP8.5 scenarios were used in order to understand the projected potential impact of extremes (Table 2) and are discussed in detail in $[43,44]$.

\subsubsection{Statistical and Probability Density Function (PDF)} Analysis. A trend analysis of rainfall and temperature extremes was carried out by using the Mann-Kendall (MK) test. The nonparametric MK test was applied to determine the significance of the monotonic trend in rainfall and temperature extreme indices $[45,46]$. Similarly, the nonparametric Sen's slope estimator $[47,48]$ was employed to
TABLE 2: Representative concentration pathways considered in this study.

\begin{tabular}{lc}
\hline RCP & Forcing \\
\hline RCP4.5 & $\begin{array}{c}\text { Stabilization scenario whereby the total radiative } \\
\text { forcing is stabilized shortly after } 2100 . \text { This will be } \\
\text { achieved by adopting several technologies and } \\
\text { strategies to cut GHG emissions [43]. }\end{array}$ \\
\hline RCP8.5 $\quad \begin{array}{c}\text { It is characterized by raising radiative forcing } \\
\text { pathways leading to } 8.5 \mathrm{~W} \cdot \mathrm{m}^{-2} \text { by } 2100, \text { with forcing } \\
\text { increasing further thereafter up to } 12 \mathrm{~W} \cdot \mathrm{m}^{-2} \text { by } 2250, \\
\text { when concentrations stabilize [44]. }\end{array}$ \\
\hline
\end{tabular}

quantify the slope of rainfall and temperature change over Ethiopia. Moreover, PDFs are calculated for the baseline period and future projected rainfall and temperature extremes to show the spatiotemporal variability of the projected change under RCP4.5 and RCP8.5 scenarios. The probability was calculated using kernel density estimation (KDE), and KDE is a nonparametric approach that can be used for estimating PDFs as described in [49].

\section{Results and Discussion}

3.1. Seasonal Rainfall Variation. Rainfall over the tropical semiarid and arid areas is characterized by high interannual variability [50]. Therefore, understanding the seasonal rainfall performance is important for agriculture, water, energy, and other socioeconomic activities. As indicated in Figures 2 and 3, the seasonal rainfall over Ethiopia was 


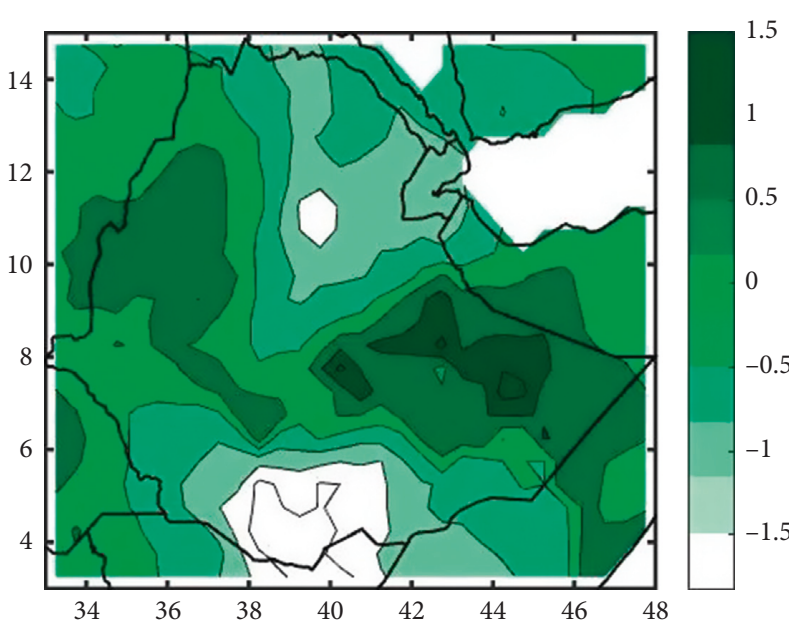

(a)

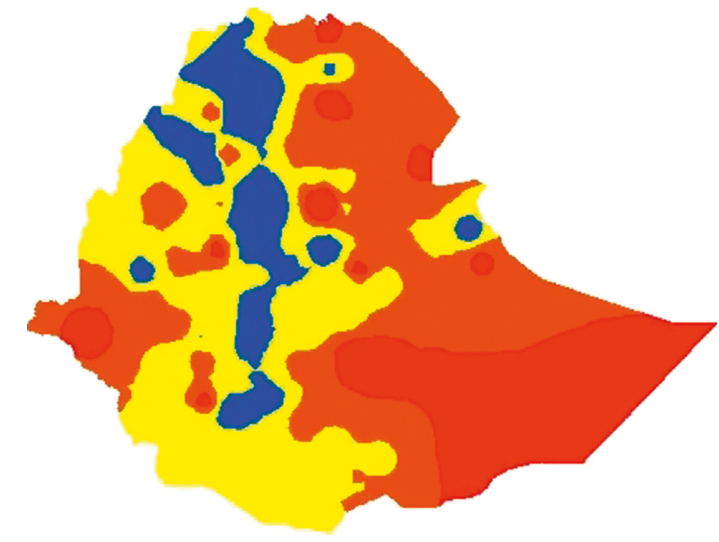

-2 and less

-1.5 to -1.99

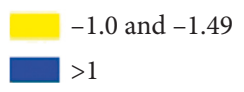

(c)

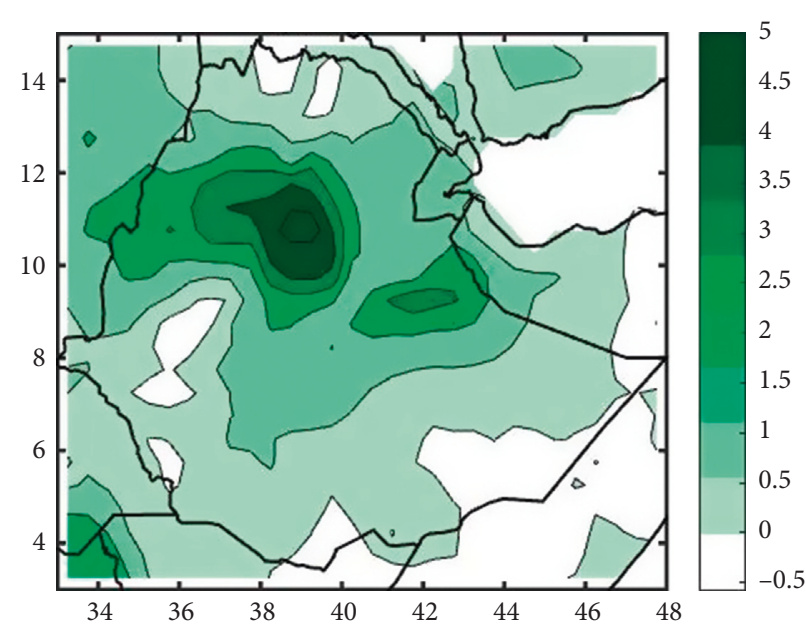

(b)

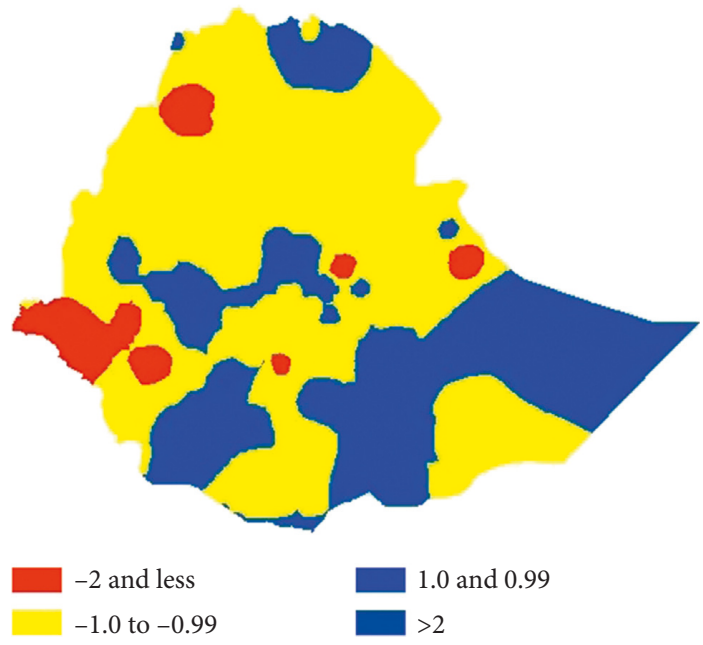

(d)

FIgURE 2: Contour-based spatial rainfall variability of (a) FMAM and (b) JJAS seasons. Standardized rainfall anomaly of (c) FMAM and (d) JJAS seasons.

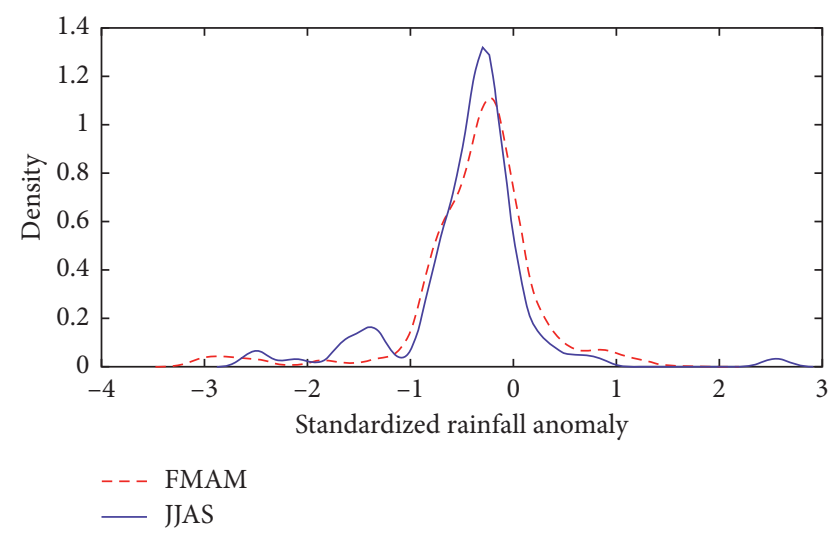

Figure 3: Probability density function (PDF) plot of the FMAM and JJAS standardized rainfall anomaly.

erratic both spatially and temporally during 1980 to 2010 . The FMAM seasonal standardized rainfall anomaly revealed significant variability over eastern, southeastern, northern, and northeastern portions of the country (Figures 2(c) and 3). This is similar to previous studies of Bekele-Biratu et al. [51] who reported that the February-May rainy season contributes up to $40 \%$ of the annual rainfall over northeastern, central, and southwestern Ethiopia and is characterized by significant interannual and intraseasonal variability. The JJAS seasonal standardized rainfall anomaly result indicated that it was variable and erratic over eastern, northwestern, and southwestern parts of Ethiopia (Figures 2(d) and 3). According to Viste et al. [52], the seasonal rainfall distribution during February-May and June-September (the summer season) declined over Ethiopia for the past decades.

The contour-based seasonal rainfall analysis of FMAM and JJAS shows that, over northeastern, central, southern, and southeastern parts of the country, the seasonal rainfall is variable (Figures 2(a) and 2(b)). The probabilistic density function (PDF) plot of the standardized rainfall anomaly shows that near-normal-to-extreme drought events occurred over Ethiopia and the frequent droughts mainly 
occurred during FMAM and JJAS seasons. Because of the frequent variability and scarcity of rainfall over sub-Saharan Africa, natural hazards cause various socioeconomic losses [53]. In 2015-2016, the region faced the most intense El Niño in decades, sparking a number of droughts and flooding disasters [53]. Climate change is associated with the significant reduction in rainfall and the increase in droughts that are already apparent in some parts of Ethiopia, and droughts resulted in loss of human life, livestock, and property, as well as migration of people [54].

The EOF analysis of seasonal rainfall over Ethiopia showed a decreasing trend (Figure 4). The three leading modes of EOF during FMAM indicated $49.6 \%, 14.2 \%$, and $8.4 \%$, respectively. The first mode of EOF shows that $49.6 \%$ was mostly negative with a high amount of seasonal rainfall variability and a general drying trend over eastern and northeastern parts, whereas the second and third modes show EOF2 variability with a small positive trend over few parts of Ethiopia (Figure 4).

The principal component analysis (PCA) of FMAM seasonal rainfall shows variability during 1980, 1981, 1983, 1984, 1991, 1993, 2010, 2012, 2013, and 2015 (Figure 4). Moreover, the three leading modes of JJAS indicated 38.4\%, $21.2 \%$, and $10.9 \%$, respectively, and the first mode shows that $38.4 \%$ was a positive trend over most parts of Ethiopia (Figure 4). The second mode of EOF revealed a positive trend over most parts and a negative trend over northwestern Ethiopia, while the third mode of JJAS EOF showed a negative trend over northern, northeastern, northwestern, and eastern parts and also a positive trend over southwestern, central, and southern parts of Ethiopia (Figure 4). The PCA time-series plot shows that the JJAS seasonal rainfall is variable during 1980, 1981, 1983, 1984, 1990, 2005, 2011, 2012, 2013, 2014, and 2015. The intraseasonal and interannual variability of rainfall over tropical and extratropical areas is teleconnected with the global atmospheric and oceanic parameters $[55,56]$.

\subsection{Climate Extreme Analysis}

3.2.1. Observed Precipitation Extremes. Climate extremes such as drought and flood affect various socioeconomic activities, and understanding the intensity and frequency of extreme climate is very important [57]. The annual rainy day extremes are characterized by strong variability with a significant trend during 1980 to 2010 (Table 3; Figure 5). Precipitation extremes like RX1day, RX5day, CWD, R10, R20, R99p, and PRCPTOT over Addis Ababa show a decreasing trend. RX1day, RX5day, SDII, and CDD over Combolcha show an increasing trend, while CWD, R10, $\mathrm{R} 20$, and annual total precipitation (PRCPTOT) show a decreasing trend (Table 3). The precipitation extremes of RX1day, RX5day, SDII, and R25 show an increasing trend, while annual total precipitation shows a decreasing trend over Jimma. Overall, it is seen that consecutive dry days shows an increasing trend, and this phenomenon is conducive to drought occurrence, while the consecutive wet days shows a decreasing trend over Ethiopia. In contrast, the number of heavy precipitation days at R10 and R20 also
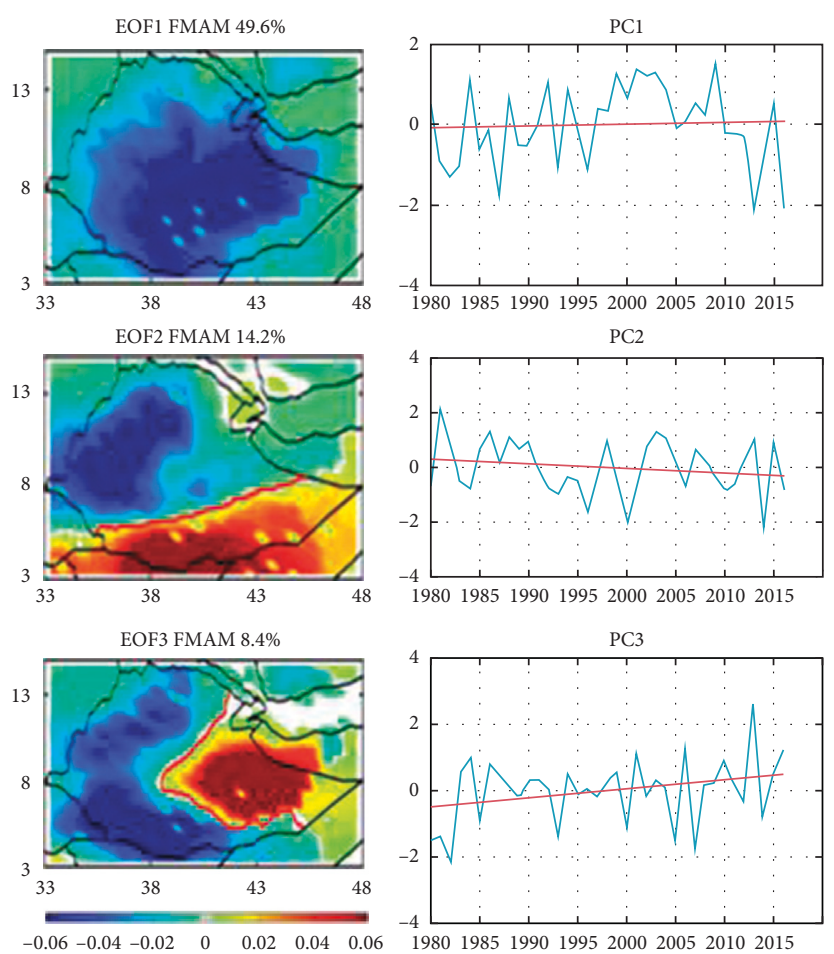

(a)
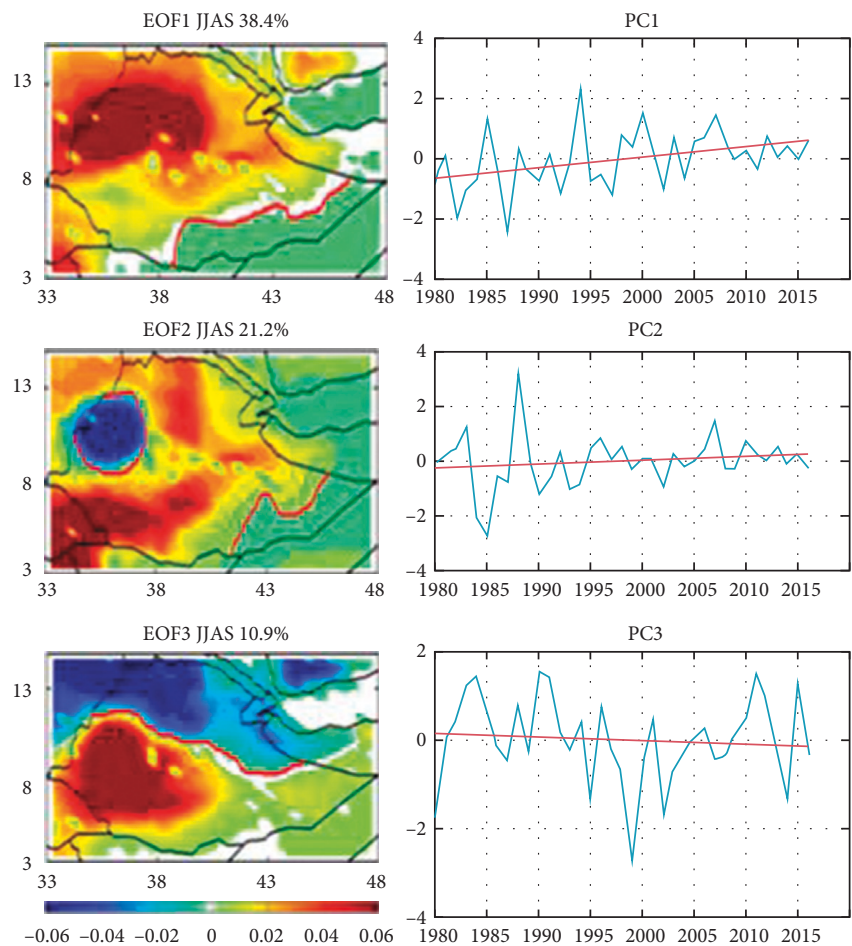

(b)

Figure 4: Three leading modes of EOF and principal component analysis (PCA) of FMAM (a) and JJAS (b) seasonal precipitation.

shows variability and a decreasing trend in most recent years. This is similar to that reported in previous studies of Omondi et al. [20] who reported continuous variability and reduction of the number of heavy rainy days over the Greater Horn of Africa including Ethiopia. 
TABLE 3: Observed temperature and precipitation extremes for selected stations.

\begin{tabular}{|c|c|c|c|c|c|}
\hline Elements & Indices & Addis Ababa & Combolcha & Jimma & Units \\
\hline \multirow{10}{*}{ Temperature } & TMAXmean & 0.02 & 0.015 & 0.031 & ${ }^{\circ} \mathrm{C}$ \\
\hline & TMINmean & 0.05 & $0.013^{*}$ & 0.027 & ${ }^{\circ} \mathrm{C}$ \\
\hline & SU25 & $0.590^{*}$ & 1.175 & 1.127 & days \\
\hline & TR20 & 0 & 0 & 0 & days \\
\hline & TXx & 0.012 & 0.01 & 0.018 & ${ }^{\circ} \mathrm{C}$ \\
\hline & $\mathrm{TNx}$ & 0.025 & $0.027^{*}$ & $0.023^{*}$ & ${ }^{\circ} \mathrm{C}$ \\
\hline & TXn & 0.03 & 0.013 & $0.019^{*}$ & ${ }^{\circ} \mathrm{C}$ \\
\hline & $\mathrm{TNn}$ & 0.085 & -0.017 & $0.025^{*}$ & ${ }^{\circ} \mathrm{C}$ \\
\hline & WSDI & $0.477^{*}$ & $0.534^{*}$ & 0.002 & ${ }^{\circ} \mathrm{C}$ \\
\hline & DTR & -0.031 & 0.003 & 0.008 & ${ }^{\circ} \mathrm{C}$ \\
\hline \multirow{11}{*}{ Precipitation } & RX1day & $-0.046^{*}$ & $0.171^{*}$ & $0.059^{*}$ & $\mathrm{~mm}$ \\
\hline & RX5day & $-0.265^{*}$ & $0.101^{*}$ & $0.124^{*}$ & $\mathrm{~mm}$ \\
\hline & SDII & -0.001 & $0.006^{*}$ & $0.011^{*}$ & $\mathrm{~mm} /$ day \\
\hline & R10 & $-0.110^{*}$ & $-0.049^{*}$ & $-0.056^{*}$ & days \\
\hline & $\mathrm{R} 20$ & $-0.031^{*}$ & $-0.019^{*}$ & $-0.010^{*}$ & days \\
\hline & R25 & $0.002^{*}$ & -0.001 & $0.022^{*}$ & days \\
\hline & $\mathrm{CDD}$ & $-0.016^{*}$ & $0.039^{*}$ & -0.001 & days \\
\hline & CWD & $-0.052^{*}$ & $-0.041^{*}$ & $-0.013^{*}$ & days \\
\hline & R95p & 0.022 & 0.975 & 0.987 & $\mathrm{~mm}$ \\
\hline & R99p & -0.006 & 0.429 & 0.466 & $\mathrm{~mm}$ \\
\hline & PRCPTOT & $-1.727^{*}$ & $-0.656^{*}$ & $-1.339^{*}$ & $\mathrm{~mm}$ \\
\hline
\end{tabular}

Note: values for trends significant at the $5 \%$ level are shown in bold.
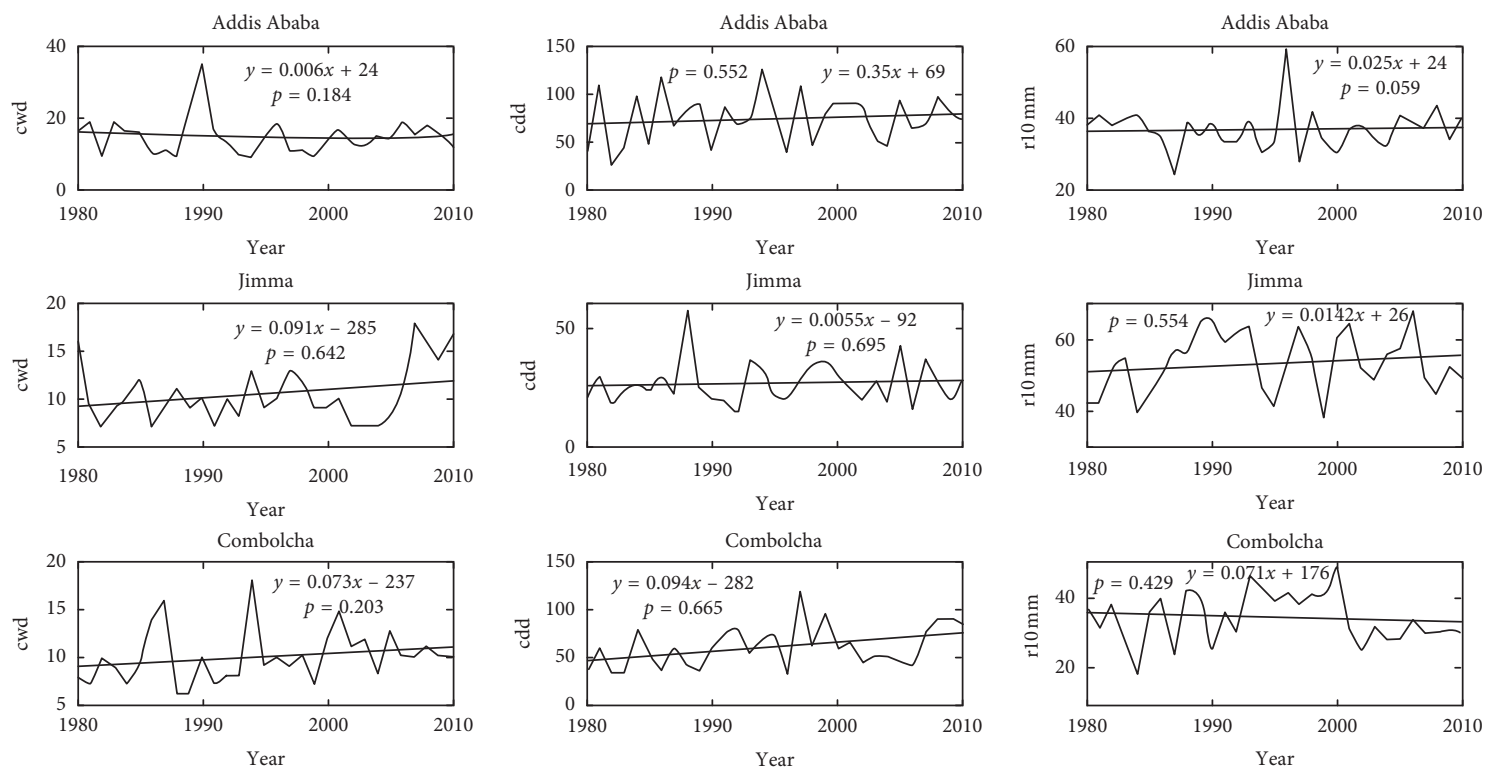

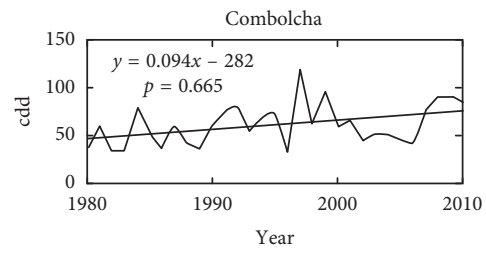

(b)

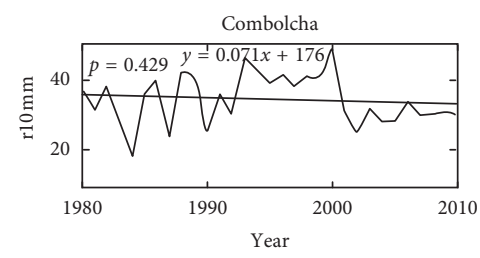

(c)

FIGURE 5: Time-series plot of consecutive wet days (a), consecutive dry days (b), and the number of heavy precipitation days at 10 mm (c).

Despite the observed variability in extreme precipitation events, continuous monitoring of extreme weather and climate events in Ethiopia is necessary. Because of the variability, intensity, and frequency of precipitation extremes during the main rainy season, frequent drought and flood occurred and affected various socioeconomic activities, predominantly in agricultural and water resource sectors (Figure 6). It is increasingly clear that many African countries are already experiencing erratic impacts of climate change [60]. Drought and hydrometeorological hazards are the main causes of mortality and economic losses in subSaharan Africa [61]. Additionally, the variability of rainfall performance over Ethiopia shows droughts and floods from the 1980s onwards, and since 1990, the country has recorded major floods that killed about 2,000 people and affected close to 2.2 million people $[62,63]$. Figure 6 indicates a chronology of Ethiopian drought and flood extreme events during different time periods. 


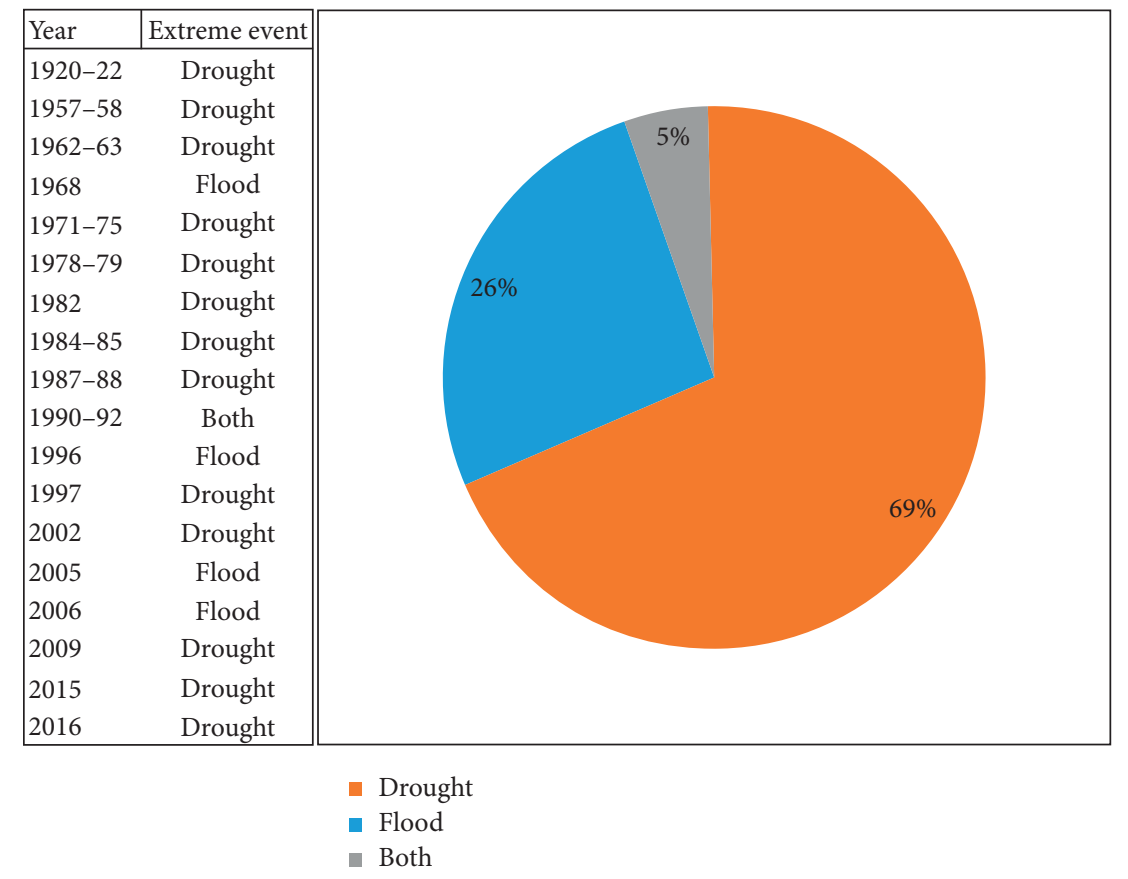

Figure 6: A chronology of extreme events over Ethiopia from 1920 to 2016 compiled and sourced from the studies in [58, 59] and from EMDAT: The OFDA/CRED International Disaster Database (http://www.emdat.be).

3.2.2. Observed Temperature Extremes. The annual mean maximum and minimum temperatures had a slight increasing trend at 0.02 and $0.05,0.03$ and 0.027 , and 0.015 and $0.013^{\circ} \mathrm{C}$ per decade over Addis Ababa, Jimma, and Combolcha, respectively, during 1980 to 2010, and the increment is high over Combolcha (Table 3). The increment rate is most likely similar to the global rate $\left(0.13^{\circ} \mathrm{C}\right.$ per decade) [1]. The temperature extremes of summer days (SU25), daily maximum temperature (TXx), and daily minimum temperature $(\mathrm{TNx})$ indicate an increasing trend, and the warm spell duration indicator (WSDI) over Addis Ababa and Combolcha shows a significantly increasing trend (Table 3; Figure 7). The monthly minimum value of daily maximum temp. (TXn) and minimum value of daily minimum temp. (TNn) extremes also show an increasing trend over Jimma and a decreasing trend over Combolcha (Table 3). The observed temperature extremes show continuous warming during 1980 to 2010. Over the last 50 years, observed surface warming over land has been associated with relatively larger increases in daily minimum temperature (Tmin) than in maximum temperature though both show significant increases and extreme climate events which often have the most impact on nature and society $[64,65]$.

Diurnal temperature range (DTR) is a measure of the difference between daily maximum and minimum temperatures at a given location. The diurnal temperature range (DTR) during 1980 to 2010 indicates a decreasing trend over Addis Ababa and an increasing trend over Combolcha and Jimma stations (Table 3). Previous studies of Dai et al. [66] revealed that clouds can reduce the DTR by $25-50 \%$ in comparison with clear sky days. On a global scale, Dai et al. [66] also simulated the DTR by using 16 scenarios, and the study noted a reduction in the DTR in all model simulations.

\subsection{Projected Climate Extremes of Precipitation and Temperature}

3.3.1. Projected Precipitation Extremes. Precipitation and temperature are very important climatic parameters as their changes may affect life conditions. So, projecting the future precipitation and temperature extremes is important for providing the general information on the trend, intensity, frequency, and changes of climate extremes and their potential impact over different socioeconomic activities [2]. To assess the changes in precipitation patterns and extremes, a number of indicators were calculated based on the ETCCDI definitions (Table 1). The spatiotemporal changes in precipitation extremes including the annual duration of consecutive wet days (CWD), total wet day precipitation (PRCPTOT), very wet days (R95p), extremely wet days (R99p), the number of heavy precipitation days (R10, R20, and R25), and simple day intensity index (SDII) show a variable and decreasing trend over Addis Ababa, Jimma, and Combolcha for the period from 2011 to 2100 (Figures 8 and 9; Table 4). Previous studies of Osima et al. [67] revealed that the projected changes in precipitation are mostly uncertain across the Greater Horn of Africa and that there is a substantial decrease over the central and northern parts of Ethiopia. Additionally, the length of dry and wet spells is projected to increase and decrease, respectively. According to the report of World Bank [63], the mean annual rainfall will decrease by $10-25 \%$ in the central highlands, by $0-10 \%$ in the south, and by more than $25 \%$ in the northern areas of the country in the coming periods. CDD, a measure of 

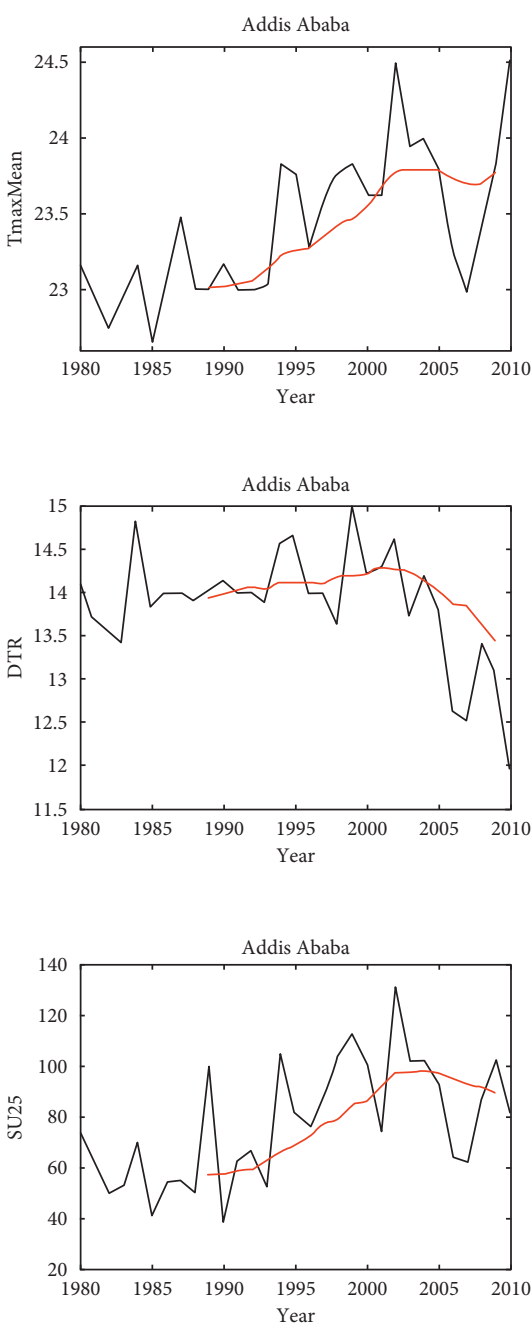
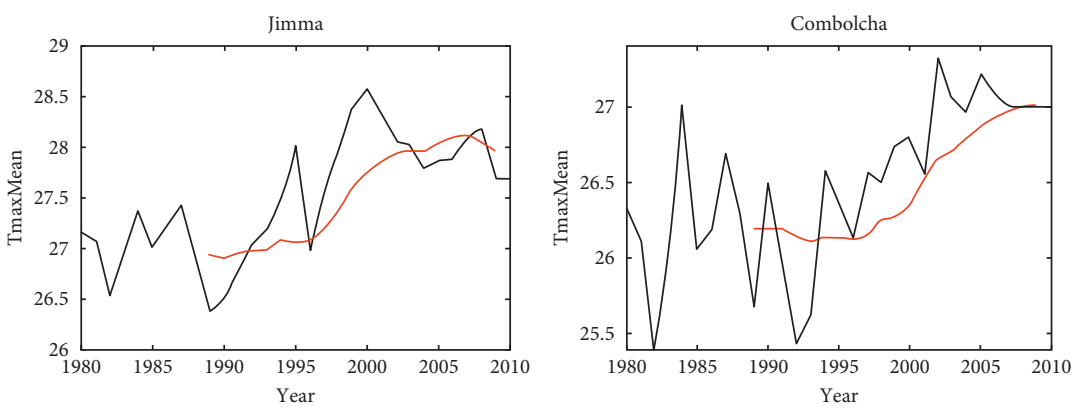

(a)
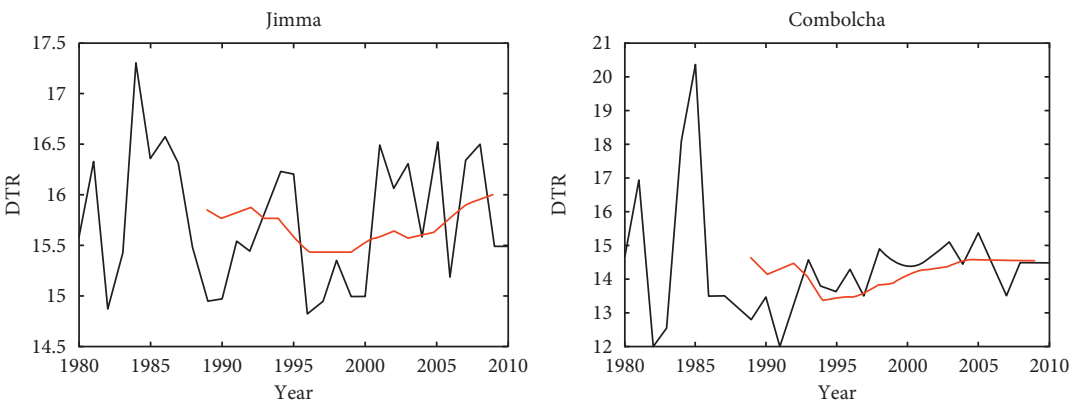

(b)
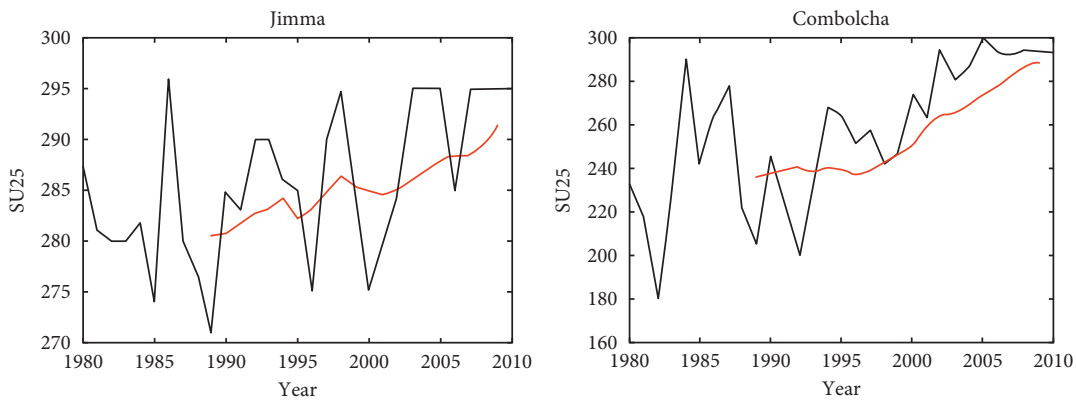

(c)

FIgURE 7: Ten-year moving average (red line) and time-series plot of TMAXmean (a), DTR (b), and SU25 (c) of temperature extremes.

extremely dry conditions, shows an increasing trend in the coming periods over Ethiopia. Any changes in rainfall patterns are likely to increase the frequency of severe droughts and floods which will subsequently have a negative impact on human and livestock health, food security, and land degradation [68].

Moreover, the projected maximum 1-day precipitation (RX1day) and maximum 5-day precipitation (RX5day) result shows a slight increasing trend over Addis Ababa and Jimma under the RCP4.5 scenario (Table 4). The latest finding is similar to that reported in previous studies of Andualem et al. [69] who reported that maximum one-day and five-day precipitation totals over a year are projected to increase over a majority of the Greater Horn of Africa including our study area. The magnitude and frequency of extreme rainfall events are very likely to increase as a result of climate change, and variation in total rainfall can be caused by a change in the frequency of rainy days or the intensity of rainfall per rainy day or a combination of both with implications for increased frequency and severity of flood disasters $[1,70]$.
The projected changes in the annual number of heavy precipitation days (R10) over Addis Ababa, Jimma, and Combolcha show a decreasing trend under RCP4.5 and RCP8.5 scenarios compared to that observed (Figure 8 ). The projected precipitation extremes show that as the rainfall performance is weak, this phenomenon is most likely to increase the intensity and frequency of drought and flood over Ethiopia. The rapid population growth and inappropriate traditional farming and management practices put intense pressure on the country's soil, water, and biodiversity resources [71]. Agriculture and water resource sectors are most likely to be heavily affected by the variability and reduced precipitation extremes and increased intensity, longer dry spells, and greater evaporation under more extreme temperatures. Water stress is already a challenge in various economic sectors [72]. To effectively address climate extreme issues, cooperation and integration, producing and using reliable weather and climate information, climate change adaptation, and ecosystem management must be sought to ensure effectiveness and efficiency in climate extreme and disaster risk governance in the coming periods over Ethiopia. 


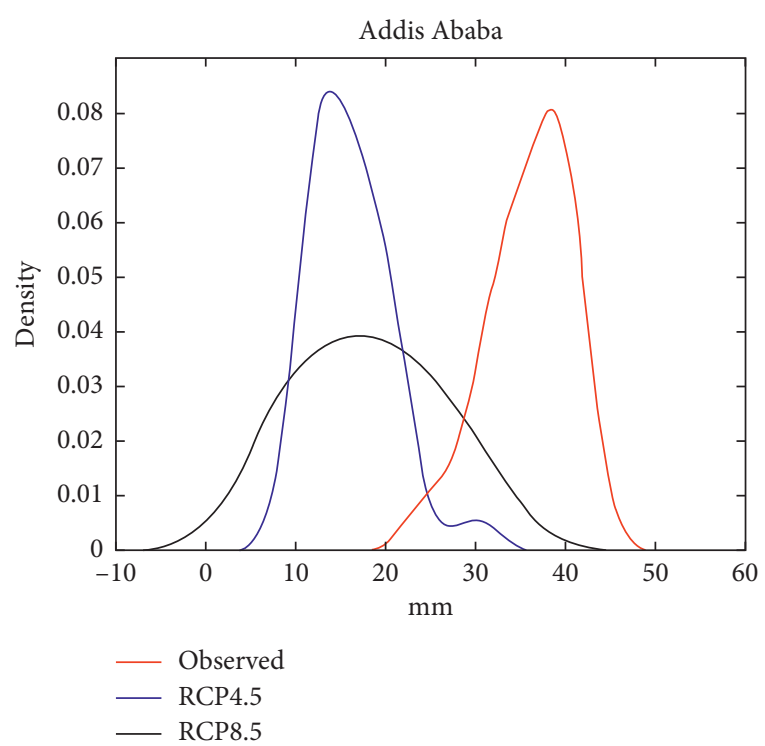

(a)

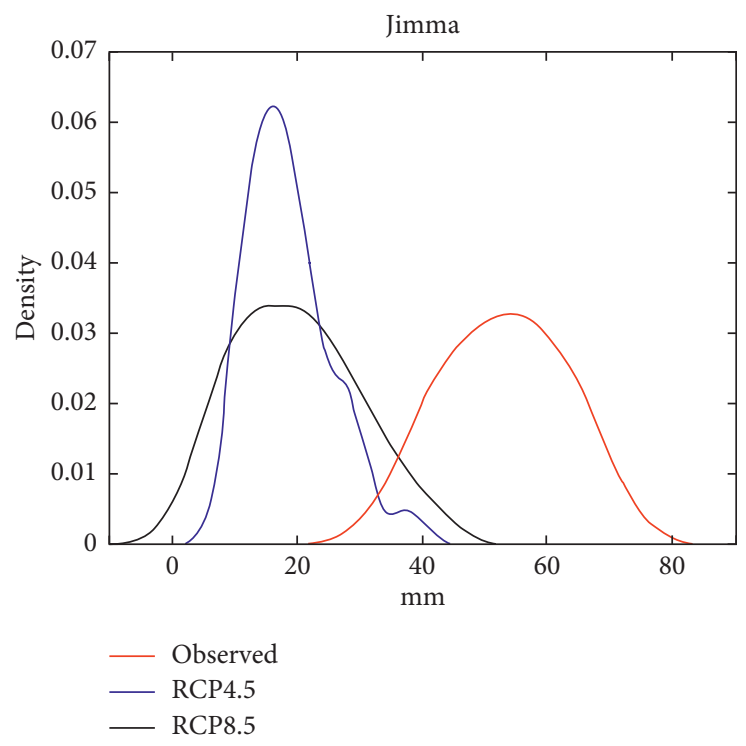

(b)

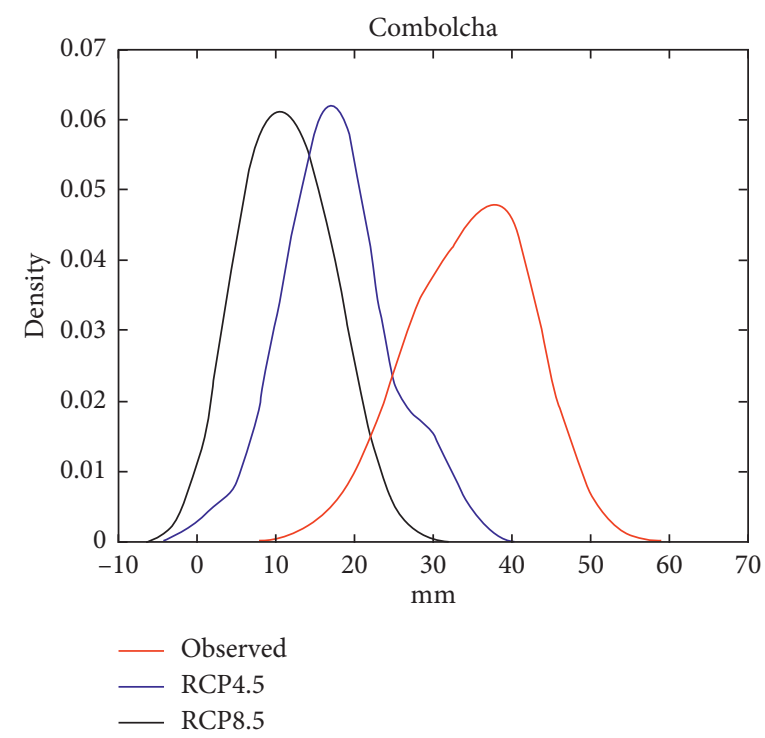

(c)

Figure 8: Comparison plot of R10 between observed and projected precipitation extremes under RCP4.5 and RCP8.5 scenarios.

The projected PRCPTOT extreme shows that the performance of precipitation is weak and variable during the period of 2011 to 2100 , and the variability is high under RCP8.5 than the RCP4.5 scenario. As pointed out by Kassie et al. [73] who reported that rainfall exhibited high interannual variability (coefficient of variation 15-40\%) during the period of 1977 to 2007 and projections for future climate suggested that annual rainfall will change by -40 to $+10 \%$ over Ethiopia. Similarly, Jury [74] indicated weak upward trends in the rainfall observed for most models over Ethiopia. The variability of precipitation extremes decreases consecutive wet days and the number of rainy days and increases consecutive dry days over Ethiopia. According to Kidanu et al. [75], the future precipitation in Ethiopia is expected to decline from a mean annual value of $2.04 \mathrm{~mm} /$ day (1961-1990) to $1.97 \mathrm{~mm} /$ day (2070-2099) with a total decline in rainfall by $25.5 \mathrm{~mm}$ /year. As pointed out by IPCC [1], climate variability and change are among the major environmental challenges of the 21st century. By contrast, under both RCP4.5 and RCP 8.5 scenarios, we observed that a significant decreasing trend in PRCPTOT increases the frequency and intensity of drought occurrence over Ethiopia (Figure 10). As indicated by World Bank [63], the climate change is predicted to reduce the gross domestic product (GDP) growth of Ethiopia between 0.5 and $2.5 \%$ each year. Because of this, the need for urgent and effective steps to build resilience is unquestionable.

3.3.2. Projected Temperature Extremes. The projected climate extremes are examined by using ensemble CMIP5 models under RCP4.5 and RCP8.5 scenarios. The results of 

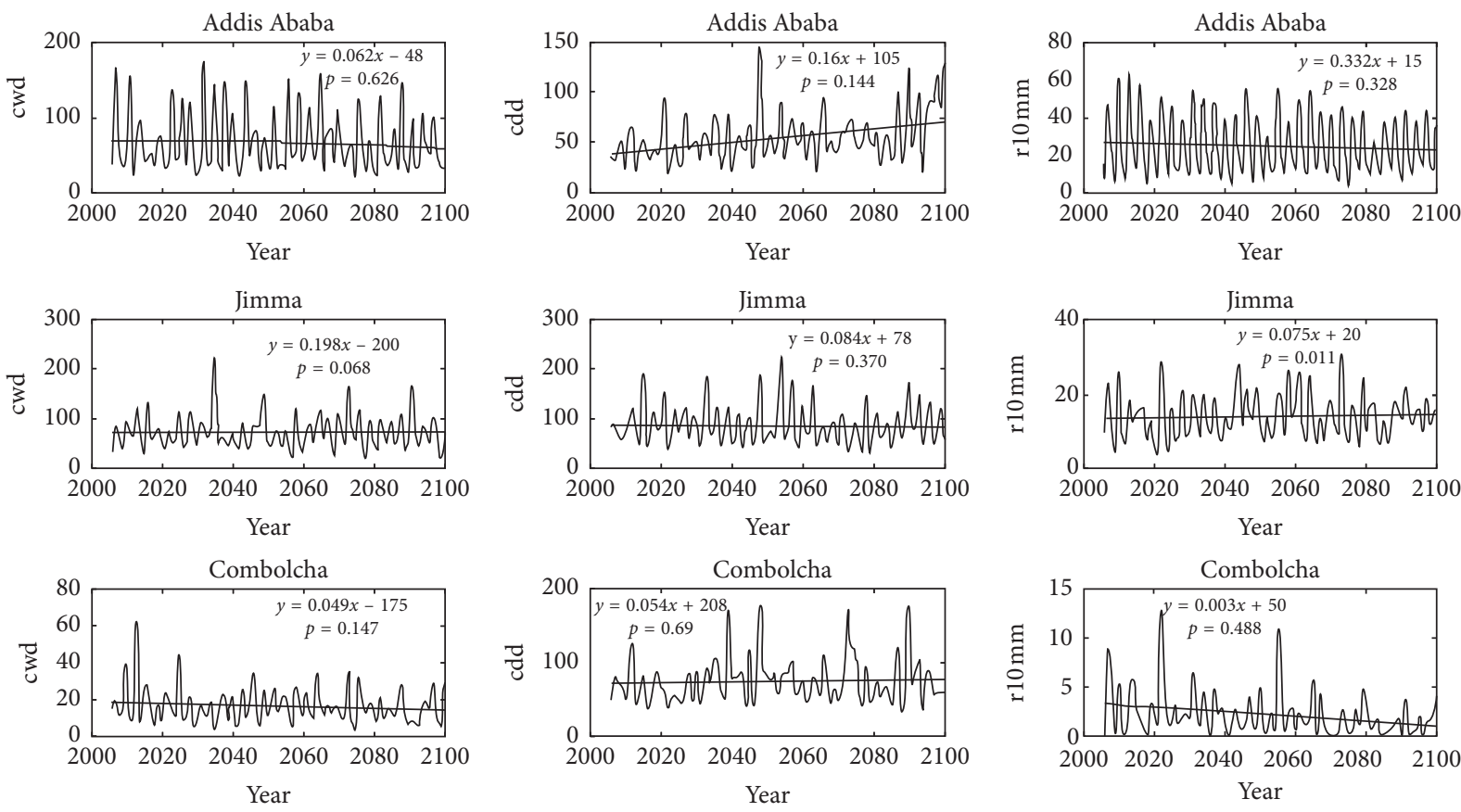

(a)

(b)

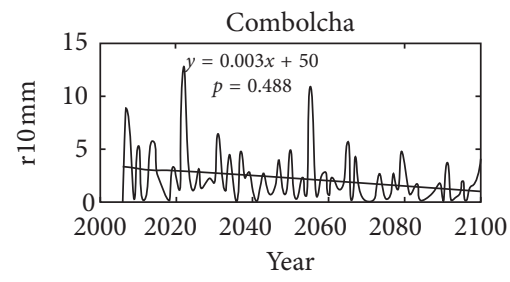

(c)

FIGURE 9: Time-series plot of ensemble consecutive wet days (a), consecutive dry days (b), and the number of heavy precipitation days at $10 \mathrm{~mm}$ (c).

TABLE 4: Projected climate extreme trend from CMIP5 ensemble models of temperature and precipitation over Ethiopia.

\begin{tabular}{|c|c|c|c|c|c|c|c|c|}
\hline \multirow{2}{*}{ Elements } & \multirow{2}{*}{ Indices } & \multicolumn{3}{|c|}{ RCP4.5 } & \multicolumn{3}{|c|}{ RCP8.5 } & \multirow{2}{*}{ Units } \\
\hline & & Addis Ababa & Combolcha & Jimma & Addis Ababa & Combolcha & Jimma & \\
\hline \multirow{11}{*}{ Temperature } & TMAXmean & 0.01 & 0.012 & 0.009 & $0.066^{* *}$ & $0.068^{* *}$ & $0.062^{*}$ & ${ }^{\circ} \mathrm{C}$ \\
\hline & TMINmean & 0.012 & 0.014 & 0.011 & 0.015 & 0.017 & 0.015 & ${ }^{\circ} \mathrm{C}$ \\
\hline & SU25 & $0.51^{* *}$ & $0.292^{*}$ & $0.136^{*}$ & 3.162 & $0.694^{*}$ & $0.538^{*}$ & days \\
\hline & TR20 & 0.002 & $0.507^{* *}$ & $0.903^{* *}$ & 0.009 & $0.708^{* *}$ & 1.107 & days \\
\hline & TXx & 0.014 & 0.016 & 0.013 & $0.068^{*}$ & $0.072^{*}$ & $0.06^{*}$ & ${ }^{\circ} \mathrm{C}$ \\
\hline & $\mathrm{TNx}$ & 0.019 & 0.018 & 0.015 & 0.019 & 0.017 & 0.013 & ${ }^{\circ} \mathrm{C}$ \\
\hline & TXn & 0.005 & 0.008 & 0.006 & $0.055^{*}$ & $0.058^{*}$ & $0.048^{*}$ & ${ }^{\circ} \mathrm{C}$ \\
\hline & $\mathrm{TNn}$ & 0.006 & 0.01 & 0.005 & 0.02 & 0.022 & 0.019 & ${ }^{\circ} \mathrm{C}$ \\
\hline & Tx90p & 0.098 & 0.106 & 0.107 & $0.511^{*}$ & $0.514^{*}$ & $0.498^{*}$ & days \\
\hline & WSDI & 0.011 & 0.009 & $0.006^{*}$ & 1.16 & 1.199 & 1.076 & days \\
\hline & DTR & -0.004 & $-0.002^{*}$ & -0.002 & $0.051^{*}$ & $0.049^{*}$ & $0.046^{*}$ & ${ }^{\circ} \mathrm{C}$ \\
\hline \multirow{10}{*}{ Precipitation } & RX1day & $0.006^{*}$ & $-0.007^{*}$ & $0.036^{*}$ & -0.008 & -0.025 & -0.014 & $\mathrm{~mm}$ \\
\hline & RX5day & $0.023^{*}$ & -0.015 & $0.06^{*}$ & -0.036 & $-0.057^{*}$ & -0.025 & $\mathrm{~mm}$ \\
\hline & SDII & 0 & -0.002 & 0.004 & -0.004 & -0.005 & -0.002 & $\mathrm{~mm} /$ day \\
\hline & $\mathrm{R} 10$ & 0.033 & -0.003 & $0.075^{*}$ & -0.113 & -0.044 & -0.031 & days \\
\hline & $\mathrm{R} 20$ & 0 & 0 & 0.002 & -0.018 & -0.003 & -0.002 & days \\
\hline & $\mathrm{CDD}$ & 0.16 & $0.054^{* *}$ & $0.084^{*}$ & 0.227 & 0.147 & 0.092 & days \\
\hline & CWD & $-0.062^{*}$ & $-0.049^{*}$ & -0.198 & -0.149 & -0.036 & 0.064 & days \\
\hline & R95p & 0.261 & $-0.048^{*}$ & 0.79 & $-0.827^{*}$ & $-0.616^{*}$ & -0.377 & $\mathrm{~mm}$ \\
\hline & R99p & 0.195 & $-0.052^{*}$ & 0.297 & $-0.382^{*}$ & $-0.32^{*}$ & -0.231 & $\mathrm{~mm}$ \\
\hline & PRCPTOT & $-0.061^{*}$ & $0.044^{*}$ & 0.495 & $-1.517^{*}$ & $-1.07^{*}$ & -0.389 & $\mathrm{~mm}$ \\
\hline
\end{tabular}

Note: ${ }^{*} 0.05$ : confidence level; ${ }^{* *} 0.1$ : confidence level.

temperature extremes like tropical nights (TR20), monthly maximum value of daily maximum temperature (TXx), monthly maximum value of daily minimum temperature (TNx), and warm spell duration indicator (WSDI) show a significant increasing trend. The projected diurnal temperature range (DTR) shows a decreasing trend over Addis
Ababa, Jimma, and Combolcha under RCP4.5 and an increasing trend under RCP8.5 (Table 5; Figures 11 and 12). This study found a pronounced warming in most of the temperature extreme indices over Ethiopia which may have potential impacts on local and regional water resources. Sillmann et al. [76] indicated that the observed changes in 

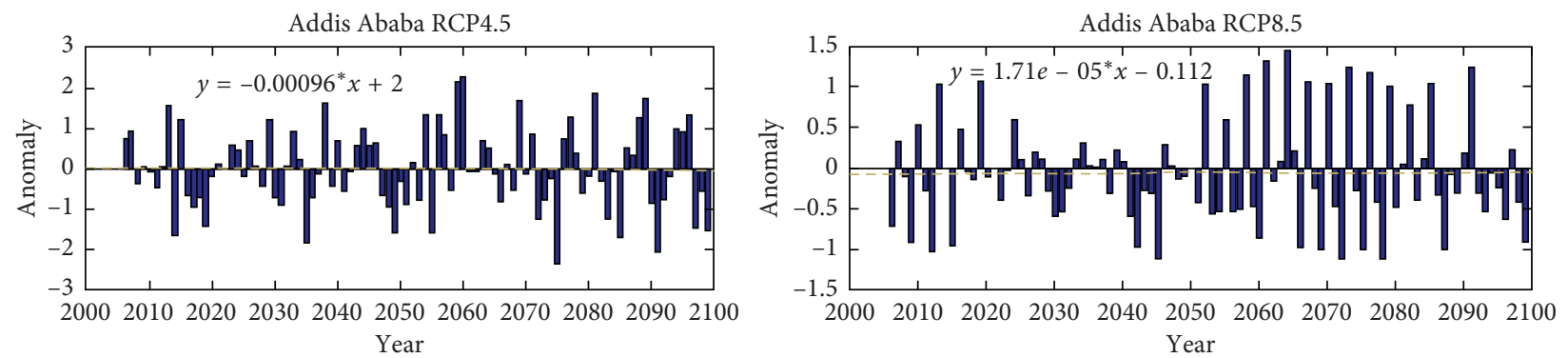

(a)
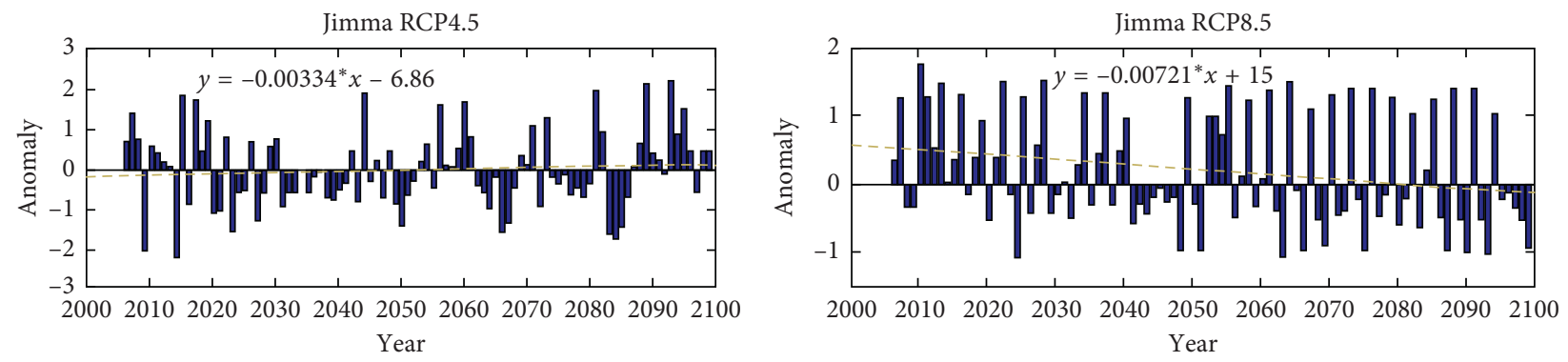

(b)
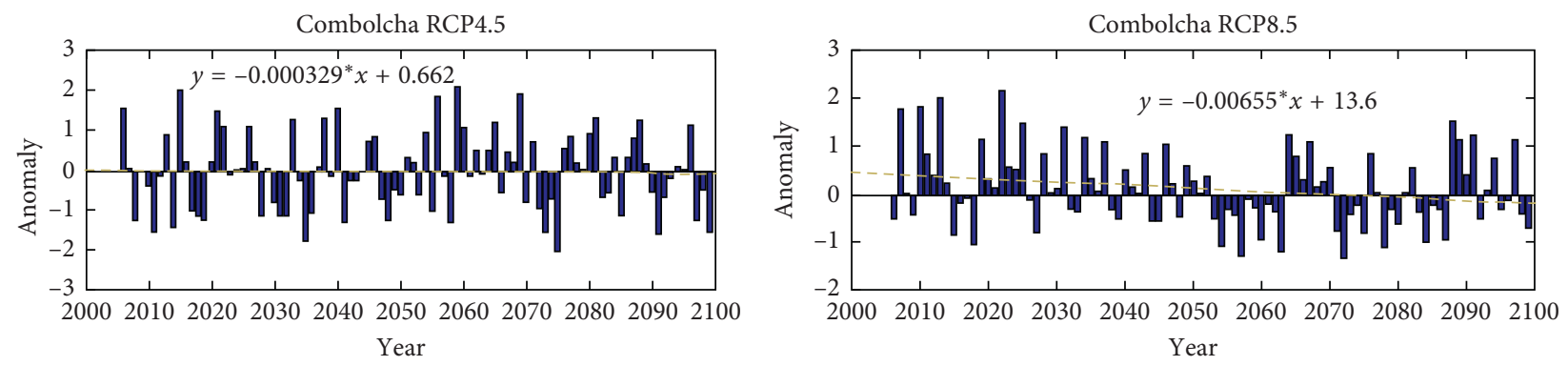

(c)

FIGURE 10: Ensemble interannual variability of the standardized precipitation anomaly (PRCPTOT) extreme over Addis Ababa (a), Jimma (b), and Combolcha (c) under RCP4.5 and RCP8.5 scenarios.

TABLE 5: Summary of the MK test statistic for precipitation and temperature extremes.

\begin{tabular}{lccc}
\hline Indices & $\mathrm{SD}$ & $Z$ & Sen's slope estimator \\
\hline CDD & 24.070 & $0.05^{*}$ & 0.48 \\
CWD & 17.020 & $-1.00^{*}$ & 0.07 \\
RX5day & 6.180 & $1.69^{*}$ & 0.06 \\
TMAXmean & 0.88 & $3.95^{* *}$ & 0.04 \\
TMINmean & 4.27 & $3.31^{* *}$ & 0.05 \\
DTR & 1.44 & $-0.44^{*}$ & 0.06
\end{tabular}

Note: ${ }^{*} 0.05$ : confidence level; ${ }^{* *} 0.1$ : confidence level; SD: standard deviation.

TNx and TXx over the entire globe were significant across land areas, and Omondi et al. [20] also observed a few extreme climate indices over GHA by using the PRECIS regional climate model (RCM) for the period 2010-2040 and indicated an increasing trend in warm days and warm nights over the region. Most of the projected temperature extremes show an increasing trend in the coming decades, and these extremes may affect various socioeconomic activities. As pointed out by Sarofim et al. [77], extreme temperature events compromise the body's normal functioning with regard to internal temperature regulation, leading to health complications. In contrast, the projected spatial analysis of percentile-based extremes shows that the frequency of cold nights (TN10) evidently decreased, while the frequency of warm nights (TN90p) is dominated by a pronounced positive trend over Ethiopia (Figure 13).

The projected extreme maximum and minimum temperatures under RCP4.5 and RCP8.5 scenarios show a consistent temperature increase throughout the projection period. The projected spatial minimum temperature increases by approximately 0.72 to $1.2^{\circ} \mathrm{C}$ and 1.6 to $2.8^{\circ} \mathrm{C}$ under RCP4.5 and RCP8.5 scenarios, respectively (Figure 12). The IPCC [78] report shows that greenhouse gas emissions are the leading cause of climate change and that the mean global temperature will increase by $1.4-5.8^{\circ} \mathrm{C}$ by the end of the 21 st century. The extreme maximum temperature change is also significant compared to the historical observed extreme events. The increment of maximum and minimum temperatures is very high over northern parts of Ethiopia (Figure 12). In contrast, the diurnal temperature range shows a decreasing trend over northeastern and southern portions of Ethiopia and 

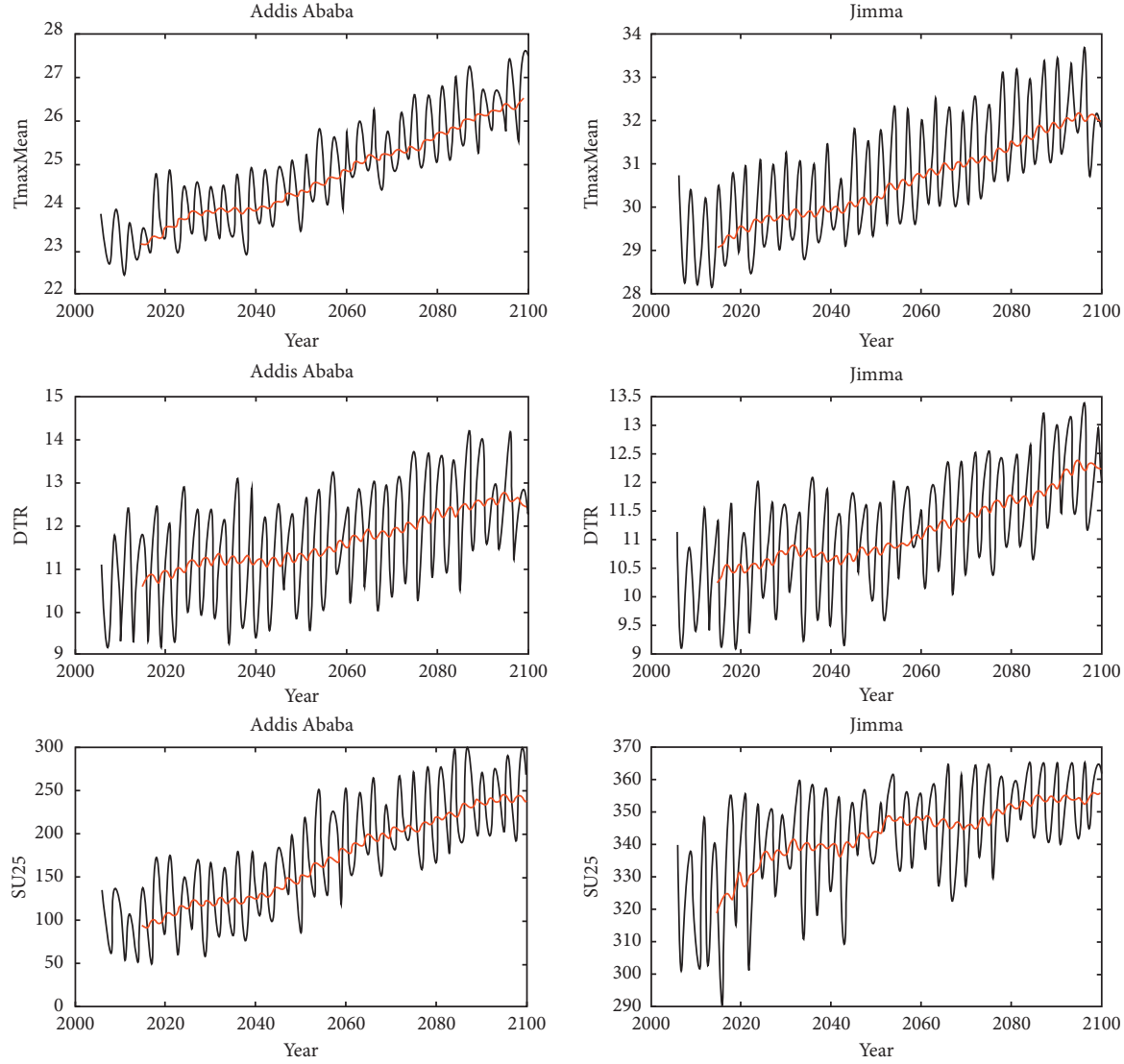

(a)

(b)
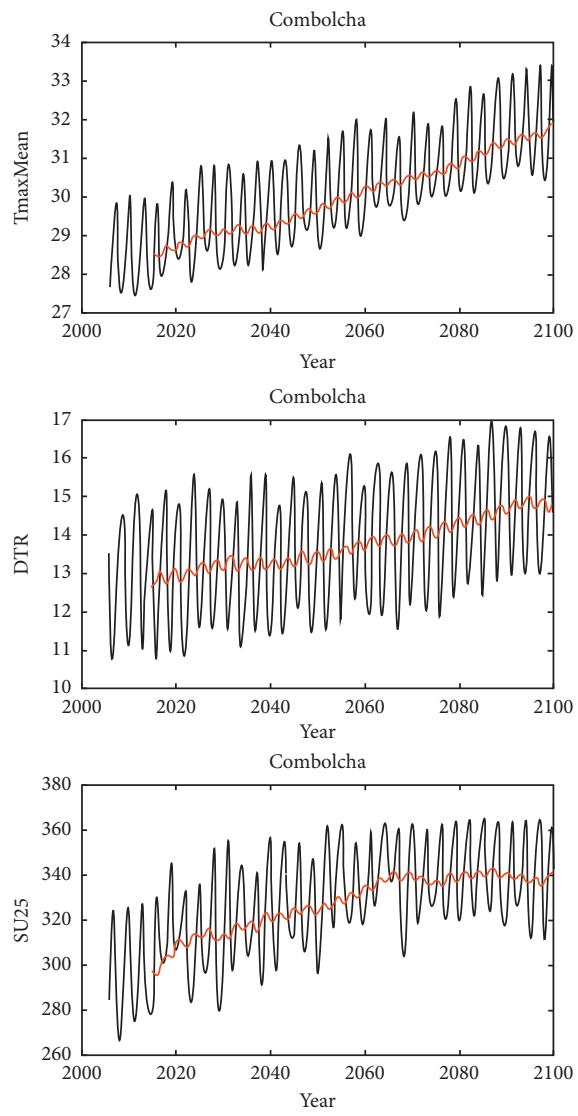

(c)

FIgURE 11: Ten-year moving average (red line) and time-series plot of projected TMAXmean (a), DTR (b), and SU25 (c) of temperature extremes. 

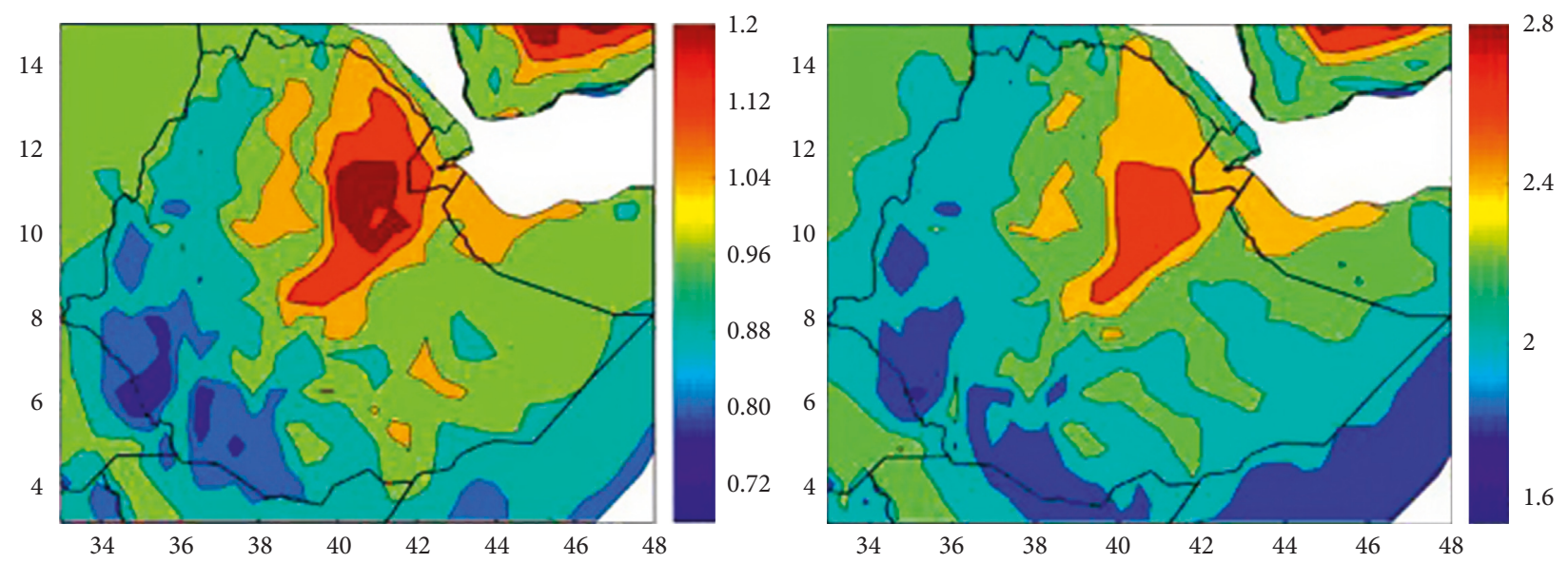

(a)
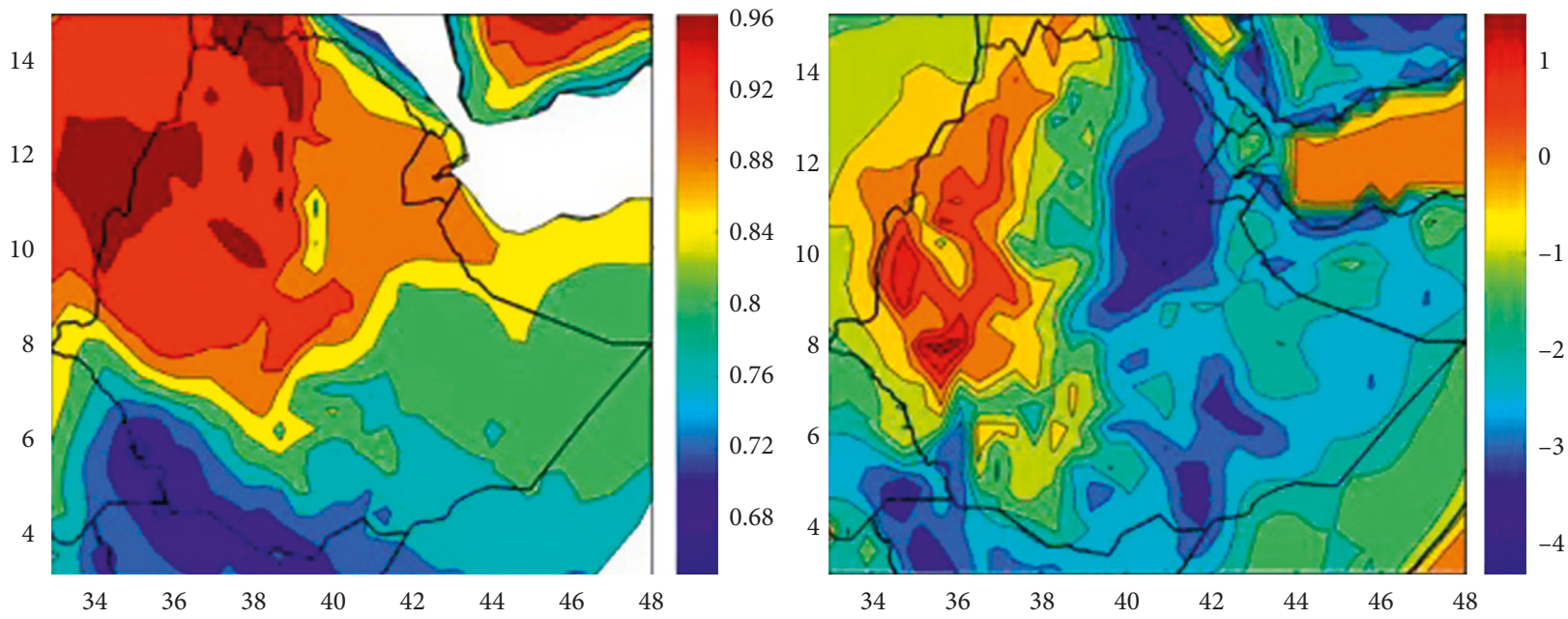

(b)

FIgURE 12: Contour-based spatial variability of extremes of TMINmean under RCP4.5 and RCP8.5 scenarios (a) and TMAXmean under RCP4.5 and DTR RCP8.5 scenarios (b).

increases over western half of the country. Figure 12 indicates that the spatial variance of temperature increases remarkably from RCP4.5 to RCP8.5 climate scenario. Previous studies of Engelbrecht et al. [79] indicated that the temperature is likely to increase by $3-5^{\circ} \mathrm{C}$ in the African tropics during 2071-2100 relative to 1961-1990 under the high-emission scenario including Ethiopia. Similarly, Dike et al. [80] observed a projected temperature increase within the African tropics varying from 3 to $7^{\circ} \mathrm{C}$ for the period 2073-2098. All of the projected temperature extremes including warm spell duration indicated an increasing trend and led towards the increase of heat waves and related disasters over Ethiopia.

\section{Summary and Conclusions}

This study examined changes of extreme temperature and precipitation by using meteorological and CMIP5 datasets of daily temperature and precipitation. The datasets were analyzed to assess the seasonal rainfall variability and changes of observed and projected climate extremes over Ethiopia under RCP4.5 and RCP8.5 scenarios. The results of the standardized seasonal rainfall anomaly and EOF analysis trend show a decreasing rainfall in the JJAS season and significant variability in the FMAM season. The first mode of EOF shows that $49.6 \%$ was mostly negative with a high amount of spatial variability during FMAM and shows a general drying trend over eastern central, northern, and northeastern Ethiopia. Trends of observed precipitation extremes of annual total precipitation (PRCPTOT), consecutive wet days (CWD), and the number of heavy precipitation days (R10 and R20) show a weak and decreasing trend, while consecutive dry days (CDD) shows an increasing trend. Similar studies of Omondi et al. [20] indicated continuous variability and reduction of the number of heavy rainy days over the Greater Horn of Africa including Ethiopia. Moreover, the observed temperature extreme shows statistically significant and spatially coherent trends in temperature extremes corresponding to a warming trend in Ethiopia. It was found that the frequency of warm spell duration indicator days has increased, while the frequency of cold days has decreased. 

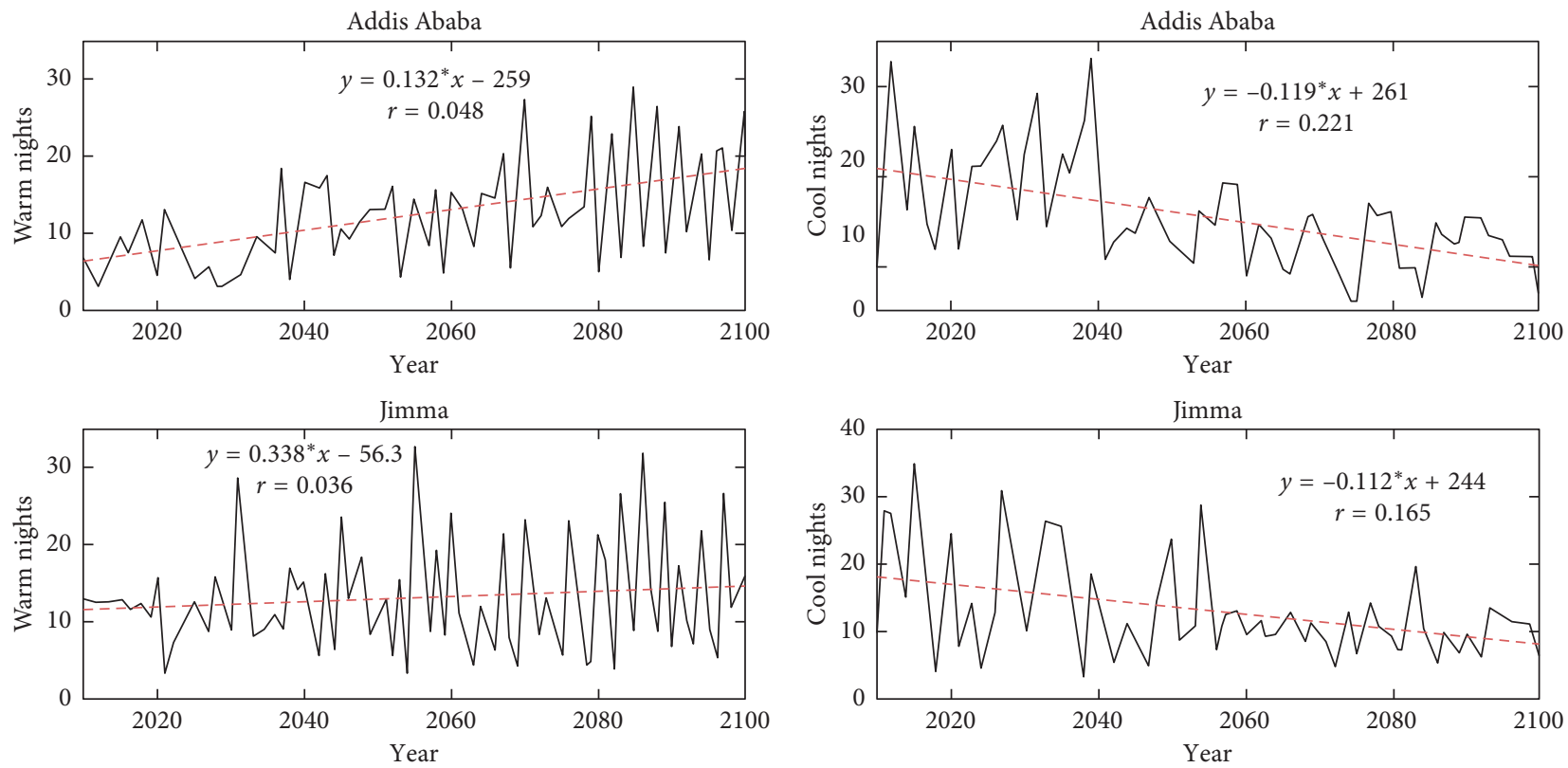

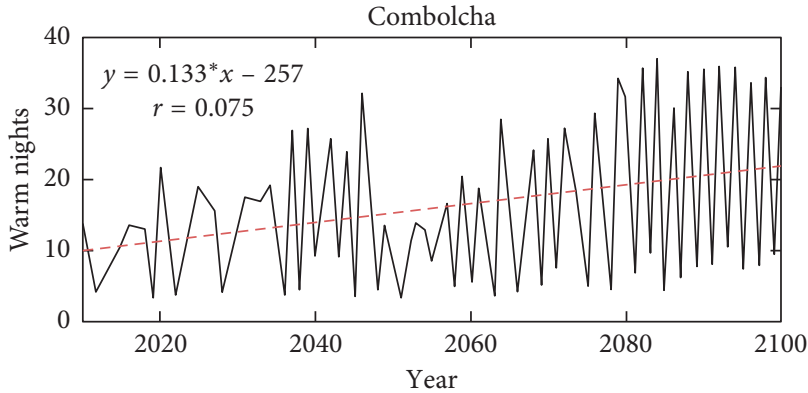

(a)

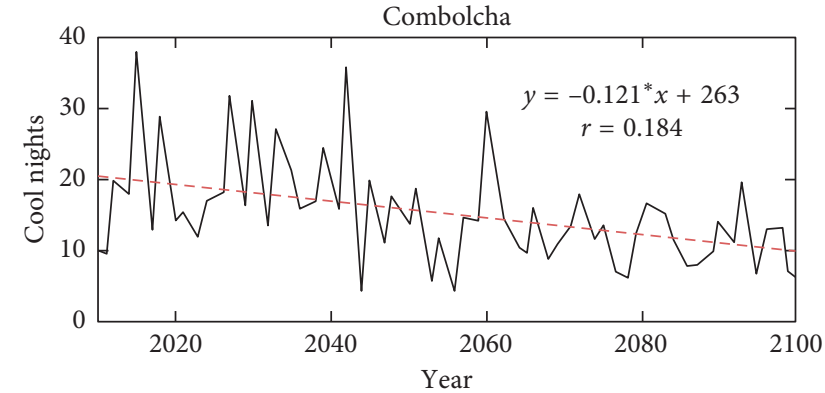

(b)

Figure 13: Projected ensemble trends of temperature extremes over Ethiopia's warm nights (a) and cold nights (b).

The projected precipitation extremes of the annual duration of consecutive wet days (CWD), total wet day precipitation (PRCPTOT), very wet day annual total (R95p), extremely wet day annual total (R99p), and the number of heavy precipitation days (R10) show a decreasing trend, whereas maximum 1-day precipitation (RX1day) and maximum 5-day precipitation (RX5day) show a slightly increasing trend and consecutive dry days (CDD) shows an increasing trend over Ethiopia. The increase (decrease) of precipitation extremes in terms of both excess and deficient extreme precipitation can cause major societal impacts including flash flooding, crop destruction, loss of life, drought, and infrastructure damage. The temperature extremes show significant warming under RCP4.5 and RCP8.5 and larger warming under the RCP8.5 scenario, while the diurnal temperature range shows a variable and declining trend over Ethiopia. The projected spatial analysis of percentile-based extremes shows that the frequency of cold nights (TN10) is decreased, while the frequency of warm nights (TN90p) is dominated by a positive trend over Ethiopia for the coming periods (Figure 13). The decrease and increase in cold and warm events indicated that the impact of climate change is real over Ethiopia for the coming periods.

Generally, the projected changes in both temperature and precipitation extremes under warming climates are likely to have significant negative impacts on the natural environment and various socioeconomic activities over Ethiopia. Additionally, the projected temperature shows that the number of hot days increases remarkably and is likely to have a severe and intensified impact on health and water resources. Therefore, producing reliable climate information, detecting and attributing climatic extremes, improving understanding of the dynamics of the climate system, and designing suitable adaptation and mitigation strategies are very important to minimize the impact of extreme climate. Moreover, this study recommends that future studies should emphasize the climatic and anthropogenic drivers responsible for changes in the trends of precipitation and temperature extremes over Ethiopia.

\section{Data Availability}

The data used to support the findings of this study are available from the corresponding author upon request.

\section{Conflicts of Interest}

The authors declare that they have no conflicts of interest. 


\section{Acknowledgments}

This research was supported by the National Key R\&D Program of China (2018YFC1507101). The authors express their appreciation to the Nanjing University of Information Science and Technology (NUIST) for encouraging and supporting research. The authors are grateful to the Ethiopian Meteorological Agency (NMA) and CMIP5 modelling groups for providing the data utilized in this study. The first author is indebted to Chinese Scholarship Council (CSC) for sponsoring his study in China.

\section{Supplementary Materials}

The supplementary material contains three sections: Section A describes the data sources which we used to conduct this manuscript. Section B and Section C summarize the software, packages, and calculation of climate extreme indices based on World Meteorological Organization (WMO) recommendations and statistical $\mathrm{MK}$ test equation analysis. (Supplementary Materials)

\section{References}

[1] IPCC, Intergovernmental Panel on Climate Change the Physical Science Basis, Cambridge University Press, Cambridge, UK, 2007.

[2] IPCC, "Managing the risks of extreme events and disasters to advance climate change adaptation," A Special Report of Working Groups I and II of the Intergovernmental Panel on Climate Change, p. 996, Cambridge University Press, Cambridge, UK, 2012.

[3] G. A. Meehl, T. F. Stocker, W. D. Collins et al., Global Climate Projections, Cambridge University Press, Cambridge, UK, 2007.

[4] I. Niang, O. Ruppel, M. Abdrabo et al., "Climate change 2014: impacts, adaptation, and vulnerability. Part B: regional aspects," in Contribution of Working Group II to the Fifth Assessment Report of the Intergovernmental Panel on Climate Change, pp. 1199-1265, Cambridge University Press, Cambridge, UK, 2014.

[5] WFP, Ethiopia Overview, World Food Program, Rome, Italy, 2015.

[6] GOE, Joint Government and Humanitarian Partners' Document, Government of Ethiopia and partners, Addis Ababa, Ethiopia, 2015.

[7] FAO, FAO in Ethiopia El Niño Response Plan 2016, Food and Agricultural Organization (FAO), Rome, Italy, 2016.

[8] L. Argaud, T. Ferry, Q. H. Le et al., "Short- and long-term outcomes of heatstroke following the 2003 heat wave in Lyon, France," Archives of Internal Medicine, vol. 167, no. 20, pp. 2177-2183, 2007.

[9] R. Basu and J. M. Samet, "Relation between elevated ambient temperature and mortality: a review of the epidemiologic evidence," Epidemiologic Reviews, vol. 24, no. 2, pp. 190-202, 2002.

[10] E. M. Kilbourne, "The spectrum of illness during heat waves," American Journal of Preventive Medicine, vol. 16, no. 4, pp. 359-360, 1999.

[11] D. R. Easterling, J. L. Evans, P. Ya Groisman, T. R. Karl, K. E. Kunkel, and P. Ambenje, "Observed variability and trends in extreme climate events: a brief review," Bulletin of the American Meteorological Society, vol. 81, no. 3, pp. 417$425,2000$.

[12] G. Meehl, T. Karl, D. Easterling et al., An Introduction to Trends in Extreme Weather and Climate Events, AMS Publications, Boston, MA, USA, 2000.

[13] C. Parmesan, T. L. Root, and M. R. Willig, "Impacts of extreme weather and climate on terrestrial biota," Bulletin of the American Meteorological Society, vol. 81, no. 3, pp. 443-450, 2000.

[14] C. Funk, M. D. Dettinger, J. C. Michaelsen et al., "Warming of the Indian Ocean threatens eastern and southern African food security but could be mitigated by agricultural development," Proceedings of the National Academy of Sciences, vol. 105, no. 32, pp. 11081-11086, 2008.

[15] B. Liebmann, M. P. Hoerling, C. Funk et al., "Understanding recent Eastern Horn of Africa rainfall variability and change," Journal of Climate, vol. 27, no. 23, pp. 8630-8645, 2014.

[16] B. Lyon and D. G. Dewitt, "A recent and abrupt decline in the East African long rains," Geophysical Research Letters, vol. 39, no. 2, 2012.

[17] R. I. Maidment, R. P. Allan, and E. Black, "Recent observed and simulated changes in precipitation over Africa," Geophysical Research Letters, vol. 42, no. 19, pp. 8155-8164, 2015.

[18] J. E. Tierney, C. C. Ummenhofer, and P. B. deMenocal, "Past and future rainfall in the Horn of Africa," Science Advances, vol. 1, no. 9, article e1500682, 2015.

[19] A. P. Williams and C. Funk, "A westward extension of the warm pool leads to a westward extension of the Walker circulation, drying eastern Africa," Climate Dynamics, vol. 37, no. 11-12, pp. 2417-2435, 2011.

[20] P. A. Omondi, J. L. Awange, E. Forootan et al., "Changes in temperature and precipitation extremes over the Greater Horn of Africa region from 1961 to 2010," International Journal of Climatology, vol. 34, no. 4, pp. 1262-1277, 2014.

[21] MoWE, Federal Democratic Republic of Ethiopia, Ministry of Water and Energy, Addis Ababa, Ethiopia, 2013, http://www. mowr.gov.et/.

[22] G. T. Diro, D. I. F. Grimes, and E. Black, "Teleconection between Ethiopian summer rainfall and sea surface temperature: part II. Seasonal forecasting," Climate Dynamics, vol. 37, no. 1-2, pp. 121-131, 2010.

[23] T. Gissila, E. Black, D. I. F. Grimes, and J. M. Slingo, "Seasonal forecasting of the Ethiopian summer rains," International Journal of Climatology, vol. 24, no. 11, pp. 1345-1358, 2004.

[24] Z. T. Segele and P. J. Lamb, "Characterization and variability of Kiremt rainy season over Ethiopia," Meteorology and Atmospheric Physics, vol. 89, no. 1-4, pp. 153-180, 2005.

[25] Y. Seleshi and G. R. Demaree, "Rainfall variability in the Ethiopian and Eritrean highlands and its links with the southern oscillation index," Journal of Biogeography, vol. 22, no. 4/5, pp. 945-952, 1995.

[26] D. Shanko and P. Camberlin, "The effects of the Southwest Indian Ocean tropical cyclones on Ethiopian drought," International Journal of Climatology, vol. 18, no. 12, pp. 13731388, 1998.

[27] W. Tsegay, El Niño and drought early warning in Ethiopia, Internet Journal of African Studies, no. 2, 1998, http://www. ccb.ucar.edu/ijas/ijasno2/georgis.html.

[28] W. Tsegay, "The case of ethiopia: impacts and responses to the 1997-98 El Niño event," in Once Burned Twice Shy? Lessons Learned from the 1997-98 El Niño, M. H. Glantz, Ed., pp. 88-100, United Nations University Press, Tokyo, Japan, 2001. 
[29] I. Harris, P. D. Jones, T. J. Osborn, and D. H. Lister, "Updated high-resolution grids of monthly climatic observations-the CRU TS3.10 Dataset," International Journal of Climatology, vol. 34, no. 3, pp. 623-642, 2014.

[30] X. L. Wang, "Comments on "detection of undocumented changepoints: a revision of the two-phase regression model"," Journal of Climate, vol. 16, no. 20, pp. 3383-3385, 2003.

[31] C. K. Folland, T. R. Karl, J. R. Christy et al., "Observed climate variability and change," in Climate Change 2001: The Scientific Basis-Contribution of Working Group I to the Third Assessment Report of the Intergovernmental Panel on Climate Change, pp. 99-181, Cambridge University Press, New York, NY, USA, 2001.

[32] P. D. Jones and M. Hulme, "Calculating regional climatic time series for temperature and precipitation: methods and illustrations," International Journal of Climatology, vol. 16, no. 4, pp. 361-377, 1996.

[33] T. C. Peterson, C. Folland, G. Gruza, W. Hogg, N. Plummer, and A. Mokssit, "Report on the activities of the working group on climate change detection and related rapporteurs 19982001," Report WCDMP-47, WMO-TD 1071, World Meteorological Organization, Geneva, Switzerland, 2001.

[34] J. P. Peixoto and A. H. Oort, Physics of Climate, American Institute of Physics, New York, NY, USA, 1992.

[35] I. T. Jolliffe, Principal Component Analysis, Springer-Verlag, New York, NY, USA, 2nd edition, 2002.

[36] H. von Storch, "Spatial patterns: EOFs and CCA," in Analysis of Climate Variability: Application of Statistical Techniques, H. von Storch and A. Navarra, Eds., Springer-Verlag, Berlin, Germany, pp. 227-257, 1995.

[37] L. J. Ogallo, "The spatial and temporal patterns of the east African seasonal rainfall derived from principal component analysis," International Journal of Climatology, vol. 9, no. 2, pp. 145-167, 1989.

[38] J. S. Babatolu and R. T. Akinnubi, "Surface temperature anomalies in the river Niger basin development authority areas, Nigeria," Atmospheric and Climate Sciences, vol. 3, no. 4, pp. 532-537, 2013.

[39] W. Bewket and D. Conway, "A note on the temporal and spatial variability of rainfall in the drought-prone Amhara region of Ethiopia," International Journal of Climatology, vol. 27, no. 11, pp. 1467-1477, 2007.

[40] K. A. Hibbard, D. P. van Vurren, and J. Edmonds, “A primer on the representative concentration pathways (RCPs) and the coordination between the climate and integrated assessment modeling communities," CLIVAR Exchanges, vol. 16, no. 2, pp. 12-15, 2011.

[41] R. H. Moss, J. A. Edmonds, K. A. Hibbard et al., "The next generation of scenarios for climate change research and assessment," Nature, vol. 463, no. 7282, pp. 747-756, 2010.

[42] K. E. Taylor, R. J. Stouffer, and G. A. Meehl, "An overview of CMIP5 and the experiment design," Bulletin of the American Meteorological Society, vol. 93, no. 4, pp. 485-498, 2012.

[43] A. M. Thomson, K. V. Calvin, S. J. Smith et al., "RCP4.5: a pathway for stabilization of radiative forcing by 2100 ," Climatic Change, vol. 109, no. 1-2, pp. 77-94, 2011.

[44] K. Riahi, S. Rao, V. Krey et al., "RCP 8.5-a scenario of comparatively high greenhouse gas emissions," Climatic Change, vol. 109, no. 1-2, pp. 33-57, 2011.

[45] H. B. Mann, "Nonparametric tests against trend," Econometrica, vol. 13, no. 3, pp. 245-259, 1945.

[46] K. MG, Rank Correlation Methods, Griffin, London, UK, 4th edition, 1975.
[47] P. K. Sen, "Estimates of the regression coefficient based on Kendall's tau," Journal of the American Statistical Association, vol. 63, no. 324, pp. 1379-1389, 1968.

[48] H. Theil, "A rank-invariant method of linear and polynomial regression analysis. I, II, III," Proceedings of the Royal Netherlands Academy of Arts And science, vol. 53, pp. 386392, 1950.

[49] A. Bernacchia and S. Pigolotti, "Self-consistent method for density estimation," Journal of the Royal Statistical Society: Series B (Statistical Methodology), vol. 73, no. 3, pp. 407-422, 2011.

[50] R. Tayeb, D. Peyman, and S. Bahram, "Annual rainfall trend in arid and semi-arid regions of Iran," in Proceedings of the ICID 21st European Regional Conference 2005, Frankfurt, Germany, May 2005.

[51] E. Bekele-Biratu, W. M. Thiaw, and D. Korecha, "Sub-seasonal variability of the belg rains in Ethiopia," International Journal of Climatology, vol. 38, no. 7, pp. 2940-2953, 2018.

[52] E. Viste, D. Korecha, and A. Sorteberg, "Recent drought and precipitation tendencies in Ethiopia," Theoretical and Applied Climatology, vol. 112, no. 3-4, pp. 535-551, 2012.

[53] World Bank, Striving toward Disaster Resilient Development in Sub-saharan Africa: Strategic Framework 2016-2020, World Bank Group, Washington, DC, USA, 2016.

[54] MoWR/NMA, Government Humanitarian Partners Joint Flood Contingency Plan for 2007 Main Rainy Season in Ethiopia, MoWR/NMA, New Delhi, India, 2007.

[55] G. T. Diro, E. Black, and D. I. F. Grimes, "Seasonal forecasting of Ethiopian spring rains," Meteorological Applications, vol. 15 , no. 1 , pp. 73-83, 2008.

[56] D. Korecha and A. G. Barnston, "Predictability of june-september rainfall in Ethiopia," Monthly Weather Review, vol. 135, no. 2, pp. 628-650, 2007.

[57] T. Watanabe, "How do irrigation and drainage play an important role in climate change adaptation?," Irrigation and Drainage, vol. 65, no. 2, pp. 189-196, 2016.

[58] NAPA, Climate Change National Adaptation Programme of Action (NAPA) of Ethiopia, National Meteorological Agency of Ethiopia, Addis Ababa, Ethiopia, 2007.

[59] T. Wolde-Georgis, D. Aweke, and Y. Hagos, Reducing the Impacts of Environmental Emergencies through Early Warning and Preparedness: The Case of the 1997-98 El Niño, National Meteorological Agency of Ethiopia, Addis Ababa, Ethiopia, 2000.

[60] R. O. Anyah and W. Qiu, "Characteristic 20th and 21st century precipitation and temperature patterns and changes over the Greater Horn of Africa," International Journal of Climatology, vol. 32, no. 3, pp. 347-363, 2012.

[61] M. Dilley, R. S. Chen, U. Deichmann, A. L. Lerner-Lam, and M. Arnold, Natural disaster hotspots: a global risk analysis, Vol. 5, World Bank Publications, Washington, DC, USA, 2005.

[62] G. J. Y. You and C. Ringler, Hydro-Economic Modeling of Climate Change Impacts in Ethiopia (No. 960), International Food Policy Research Institute (IFPRI), Washington, DC, USA, 2010.

[63] Worldbank, Ethiopia: Economics of Adaptation to Climate Change, World Bank Group, Washington, DC, USA, 2010.

[64] D. R. Easterling et al., "Maximum and minimum temperature trends for the globe," Science, vol. 277, no. 5324, pp. 364-367, 1997.

[65] T. R. Karl, R. W. Knight, K. P. Gallo et al., "A new perspective on recent global warming: asymmetric trends of daily 
maximum and minimum temperature," Bulletin of the American Meteorological Society, vol. 74, no. 6, pp. 1007-1023, 1993.

[66] A. Dai, E. Kevin, K. E. Trenberth, and T. R. Karl, "Effects of clouds, soil moisture, precipitation, and water vapor on diurnal temperature range," Journal of Climate, vol. 12, no. 8 , pp. 2451-2473, 1999.

[67] S. Osima, V. S. Indasi, M. Zaroug et al., "Projected climate over the Greater Horn of Africa under $1.5^{\circ} \mathrm{C}$ and $2^{\circ} \mathrm{C}$ global warming," Environmental Research Letters, vol. 13, no. 6, article 065004, 2018.

[68] EEA and EPRI, "Ethiopian economic association (EEA), \& economic policy research institute (EPRI)," in The Social Dimensions of Adaptation to Climate Change in Ethiopia No. 14, World Bank, Washington, DC, USA, 2010.

[69] S. Andualem, T. Tsegaye, R. Clinton, and O. Robert, "Precipitation extremes in dynamically downscaled climate scenarios over the Greater Horn Of Africa," Atmosphere, vol. 9, no. 3, p. 112, 2018

[70] M. New, M. Todd, M. Hulme, and P. Jones, "Precipitation measurements and trends in the twentieth century," International Journal of Climatology, vol. 21, no. 15, pp. 18991922, 2001.

[71] B. Simane, B. Zaitchik, and M. Ozdogan, "Agroecosystem Analysis of the choke mountain watersheds, Ethiopia," Sustainability, vol. 5, no. S2, pp. 592-616, 2013.

[72] C. Siderius, K. E. Gannon, M. Ndiyoi et al., "Hydrological response and complex impact pathways of the 2015/2016 El Niño in Eastern and Southern Africa," Earth's Future, vol. 6, no. 1, pp. 2-22, 2018.

[73] B. T. Kassie, R. P. Rötter, H. Hengsdijk et al., "Climate variability and change in the Central Rift Valley of Ethiopia: challenges for rainfed crop production," The Journal of Agricultural Science, vol. 152, no. 1, pp. 58-74, 2014.

[74] M. R. Jury, "Statistical evaluation of CMIP5 climate change model simulations for the Ethiopian highlands," International Journal of Climatology, vol. 35, no. 1, pp. 37-44, 2014.

[75] A. Kidanu, K. Rovin, and K. Hardee-Cleaveland, Linking Population, Fertility and Family Planning with Adaptation to Climate Change: Views from Ethiopia, Population Action International, Washington, DC, USA, 2009.

[76] J. Sillmann, V. V. Kharin, X. Zhang, F. W. Zwiers, and D. Bronaugh, "Climate extremes indices in the CMIP5 multimodel ensemble: part 1. Model evaluation in the present climate," Journal of Geophysical Research: Atmospheres, vol. 118, no. 4, pp. 1716-1733, 2013.

[77] M. Sarofim, S. Saha, M. Hawkins et al., "Ch. 2: temperaturerelated death and illness," in The Impacts of Climate Change on Human Health in the United States: A Scientific Assessment, pp. 43-68, U.S. Global Change Research Program, Washington, DC, USA, 2016.

[78] IPCC, Contribution of working group $i$ to the third assessment report of the intergovernmental panel on climate change Climate Change 2001: The Scientific Basis, J. T. Houghton, Y. Ding, D. J. Griggs et al., Eds., p. 881, Cambridge University Press, Cambridge, UK, 2001.

[79] F. Engelbrecht, J. Adegoke, M. J. Bopape et al., "Projections of rapidly rising surface temperatures over Africa under low mitigation," Environmental Research Letters, vol. 10, no. 8, article 085004, 2015.

[80] V. N. Dike, M. H. Shimizu, M. Diallo, Z. Lin, O. K. Nwofor, and T. C. Chineke, "Modelling present and future African climate using CMIP5 scenarios in HadGEM2-ES,"
International Journal of Climatology, vol. 35, no. 8, pp. 1784-1799, 2015. 

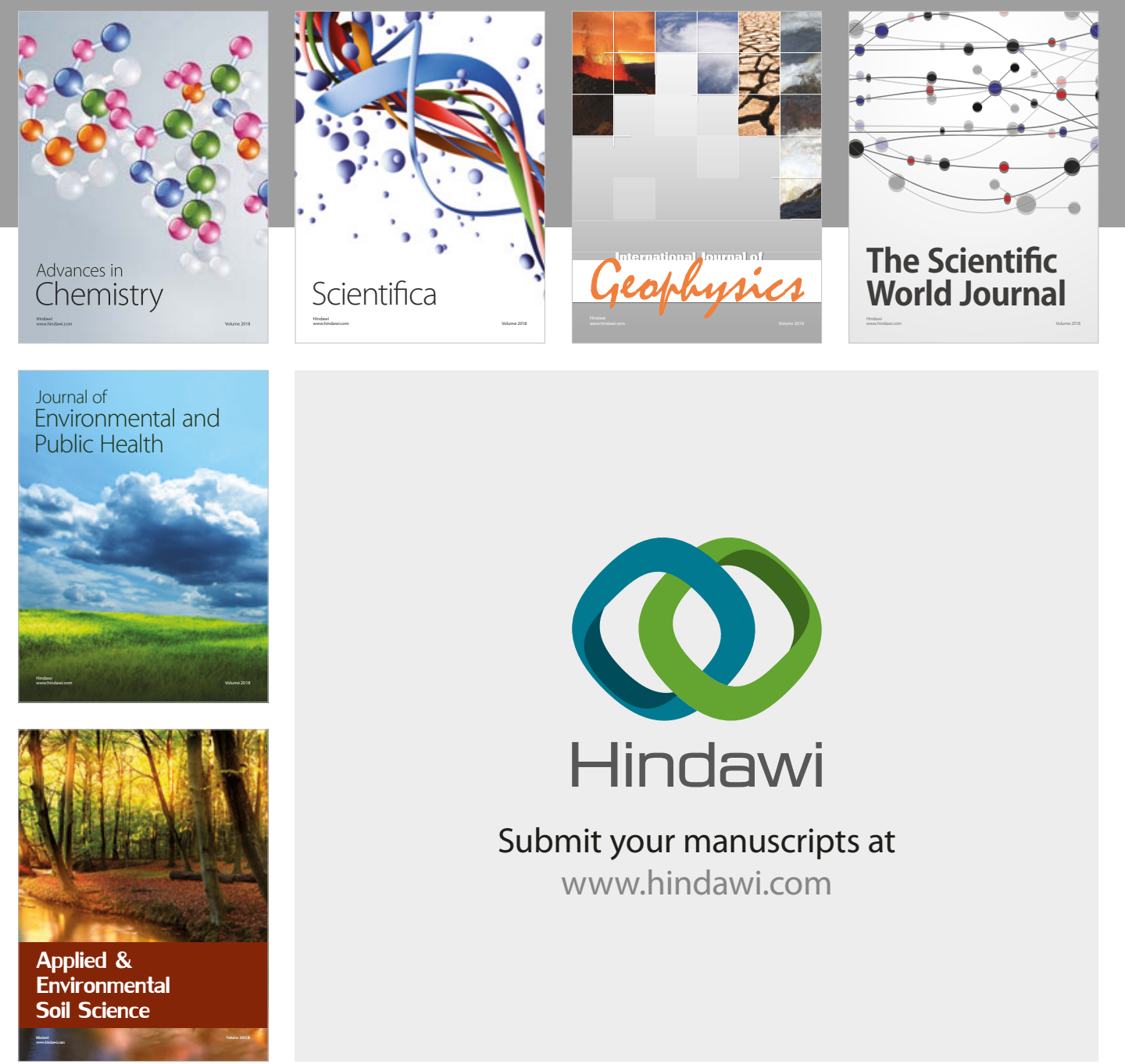

The Scientific

\section{World Journal}
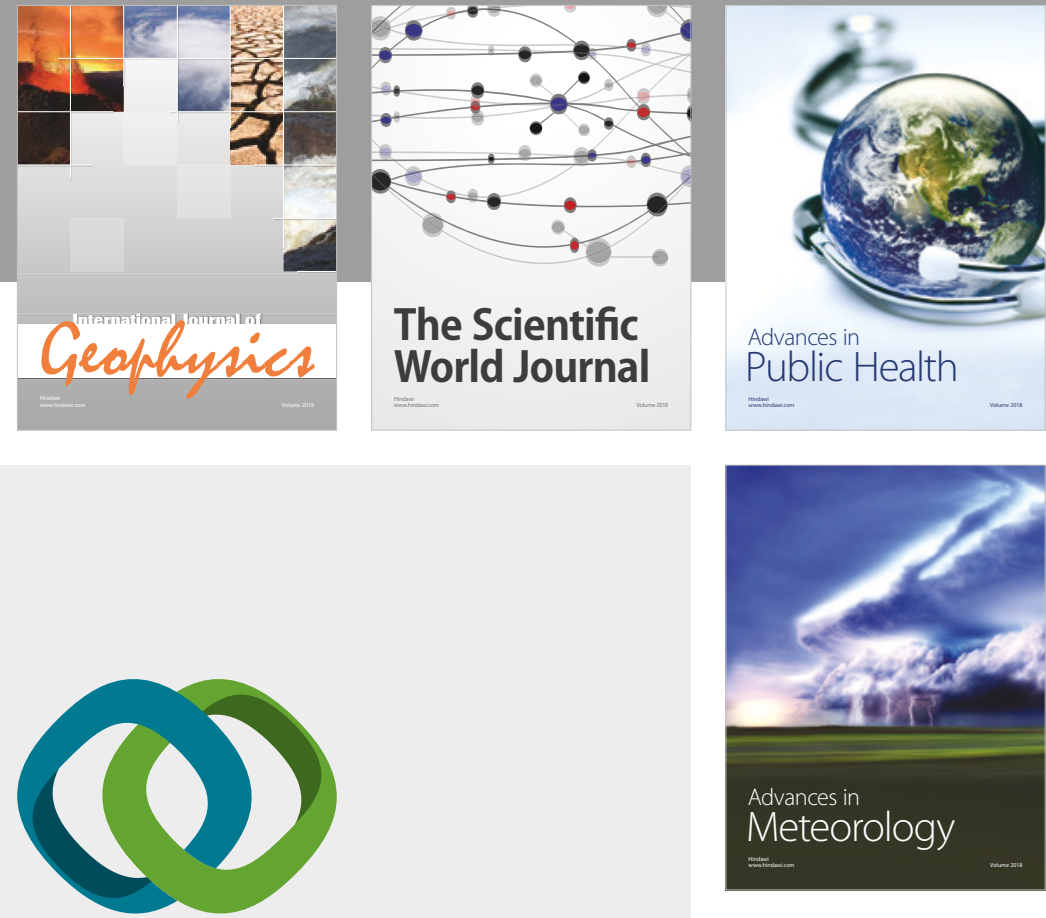

Advan

Public Health

\section{Hindawi}

Submit your manuscripts at

www.hindawi.com
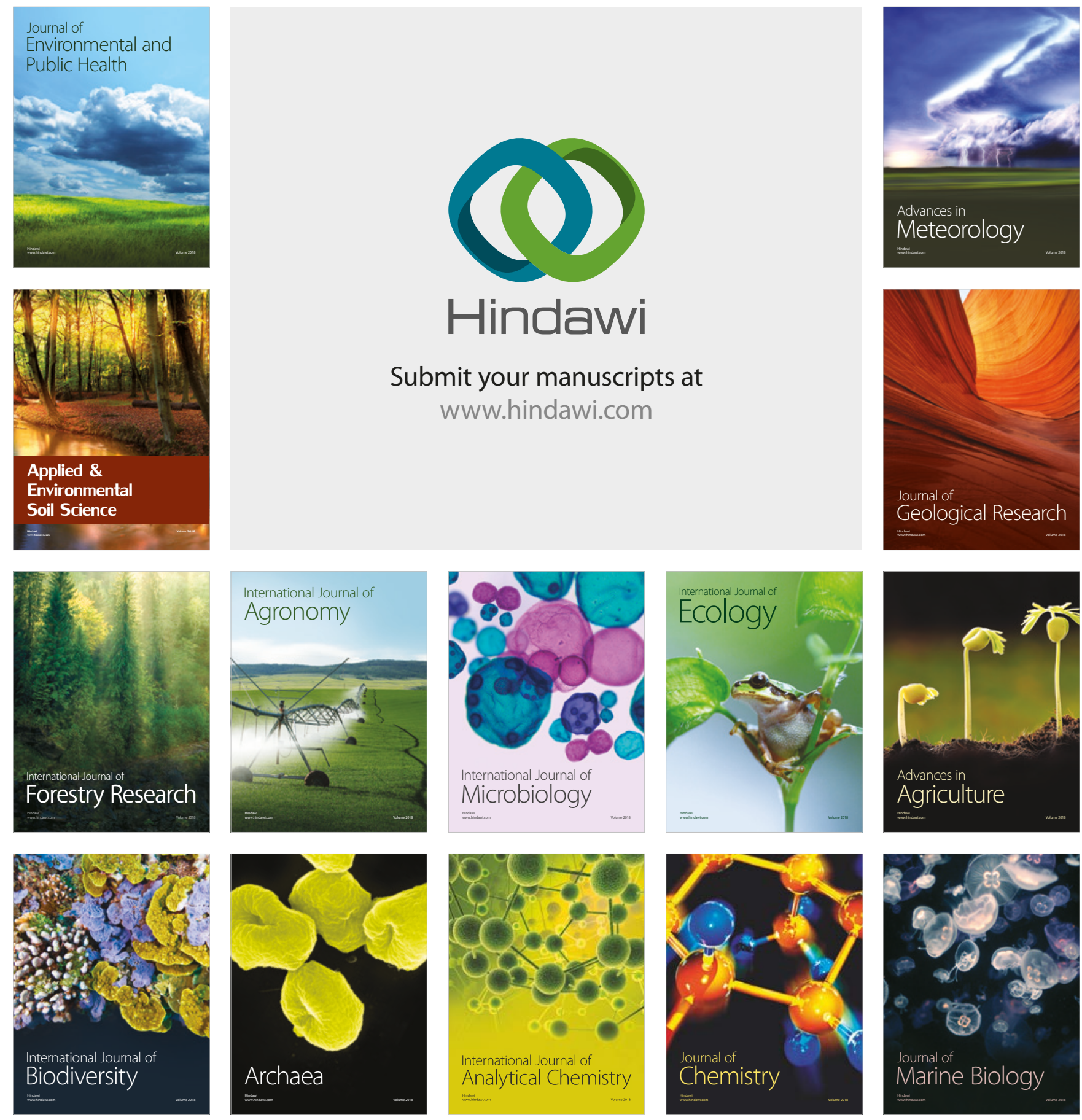